Historic, Archive Document

Do not assume content reflects current scientific knowledge, policies, or practices. 



\subsection{0

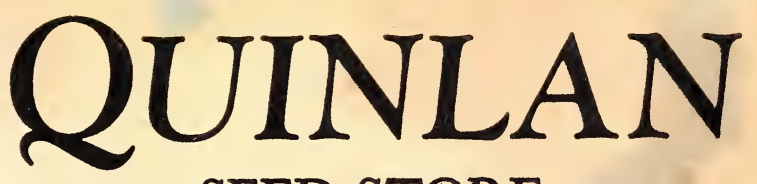 SEED STORE}

$43 x_{2}+10$
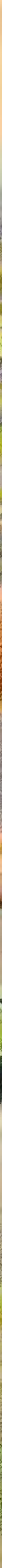


\section{Perennials the Season Through}

Perennials are assuming their proper place in our gardens. Their cultivation is a delight to all who are interested in the procession of color that advances from early spring until late fall. It is possible, by careful selection, to have flowers eight months in the year in our latitude. If one owns a home or expects to occupy one two years or more, these are the varieties to give permanence to the garden.

Some varieties, such as Canterbury Bells, are biennials (these come up the first year from seed, flower and die the next) and they should be planted each year for the next season's flowers. Some like Dianthus Barbatus (Sweet William), also biennials, multiply readily from self-sown seed and should be divided when too thick. Hollyhocks are perennials, but they also reproduce themselves by seed dropped from the parent plant.

Perennials may be secured in plants and seeds-plants for immediate effect, although some perennial seeds if sown too early bloom the same year (Gaillardia, Coreopsis and Iceland Poppies, will do this). The best time to sow perennial seed is in May and June, although they may be sown in July and August. The earlier planting secures larger plants which will winter over more successfully.

Prepare a seed bed in a sheltered position where the amount of sunshine and moisture can not be controlled; pulverize the soil and carefully sow seed in rows to the depth of not more than four times the size of the seed (fine seed to be merely covered); when seedlings are large enough, transplant in rows in the garden. In September transplant to their permanent position in the garden. In setting these it is well to dig a larger hole than the root calls for and incorporate in the bottom a trowel full of well rotted manure, covering manure with soil so that roots will not come in contact with the manure unit they are in want of additional nourishment. fall.

Perennials should be placed in groups for best effect. Plant in early spring or

After a long and tiresome winter we welcome with joy the first sunshiny days and warm spring rains, knowing that in a short time our garden will respond to their kindly influence and we will enjoy fruits of our last year's work.

Among the earliest are the dainty white Rock Cress (arabis alpina); the bright golden Alyssum (saxatile compactum). Phlox subulata rosea is a compact mass of foliage with dainty pink flowers. Viola Cornuta (tufted pansies) create an oriental carpet of splendor with their gay flowers of yellow, blue and white in all shades. These have the additional beauty of blooming all season long. The Crocus, Snowdrops (Galanthus) and grape Hyacinths (Muscari), (bulbous stock) add to the spring symphony of color.

The first flowers of spring are modest and hug close to Mother Earth. Mertensia Virginica and hardy Primroses make an ideal combination. Pink Darwin tulips are wonderful with the blue of the Mertensia. Iris pumila (not to be confused with the German and Japanese varieties which are later) grow close to the ground. Iris Florentina is followed by the long stemmed Iris which will last until early July, Myosotis Palustris (Forget-Me-Not) can be used as background of shrubs. Aquilegias (Columbine) run through a complete color range and are most charming, Mrs. Scott Elliott's long spurred strains particularly so.

The Dianthus family follows with the clove pinks (Dianthus Plumarius) and Sweet Williams (Dianthus Barbatus) making the garden fragrant and gay at the same time.

Fragrant Lily of the Valley-the bride's flower-carpets the ground in June. Polemoniums bloom from May to the end of June. Lupins follow in several attractive shades. Try Harkness' regale mixture and Downer's hybrids. Nudicaule (Iceland) Poppies are delicate subjects (try the Sunbeams). The Shasta Daisy furnishes wonderful cutting material.

Campanula or Bell flowers, now dominate the garden for several weeks with their various varieties.

Pyrethrum Roseum, or Painted Daisy is a large pink daisy-like flower like the Shasta Daisy. Delphiniums (Larkspur) particularly the dark Formosum and Indigo are at their best near the pure white Lilium Candidum. Anchusa Dropmore is a welcome blue color. The Oriental Poppies offer a blaze of color.

Hollyhocks are gay sentinels of July. It is now mid-summer and hardy Phlox in their myriad shades add to the beauty for a few weeks. Try Phlox Elizabeth Campbell with Candidum Lilies. Garden Heliotrope (Valerian Alba is delightful after a shower; lovely with Anchusa. Red perennials should be backed against green background away from other conflicting colors. Day Lilies or Hemerocallis, may be found from primrose to deep orange shades. Evening Primrose (Oenothera is another useful yellow perennial. Blue Flax (Linum Perenne) is delightful planted with Miss Lingard Phlox. Pentstemon Gentianoides and Gladiolus Primulinus make another charming arrangement. 


\section{PARCEL POST RATES}

\begin{tabular}{|c|c|c|c|c|c|}
\hline Lbs. & Local & $\begin{array}{c}\text { Zone } \\
1 \text { and } 2 \\
150 \text { miles }\end{array}$ & $\begin{array}{c}3 \text { rd } \\
150 \text { to } 300 \\
\text { miles }\end{array}$ & $\begin{array}{l}\text { 4th } \\
300 \text { to } 600 \\
\text { miles }\end{array}$ & $\begin{array}{l}5 \text { th } \\
600 \text { to } 1000 \\
\text { miles }\end{array}$ \\
\hline $\begin{array}{r}1 \\
2 \\
3 \\
4 \\
5 \\
6 \\
7 \\
8 \\
9 \\
10 \\
11 \\
12 \\
13 \\
14 \\
15 \\
16 \\
17 \\
18 \\
19 \\
20\end{array}$ & $\begin{array}{r}\$ 0.07 \\
.08 \\
.08 \\
.09 \\
.09 \\
.10 \\
.10 \\
.11 \\
.11 \\
.12 \\
.12 \\
.13 \\
.13 \\
.14 \\
.14 \\
.15 \\
.15 \\
.16 \\
.16 \\
.17\end{array}$ & $\begin{array}{r}\$ 0.07 \\
.08 \\
.09 \\
.10 \\
.11 \\
.12 \\
.13 \\
.14 \\
.15 \\
.16 \\
.17 \\
.18 \\
.19 \\
.20 \\
.21 \\
.22 \\
.23 \\
.24 \\
.25 \\
.26\end{array}$ & $\begin{array}{r}\$ 0.08 \\
.10 \\
.12 \\
.14 \\
.16 \\
.18 \\
.20 \\
.22 \\
.24 \\
.26 \\
.28 \\
.30 \\
.32 \\
.34 \\
.36 \\
.38 \\
.40 \\
.42 \\
.44 \\
.46\end{array}$ & $\begin{array}{r}\$ 0.09 \\
.13 \\
.17 \\
.21 \\
.25 \\
.29 \\
.33 \\
.37 \\
.41 \\
.45 \\
.49 \\
.53 \\
.57 \\
.61 \\
.65 \\
.69 \\
.73 \\
.77 \\
.81 \\
.90\end{array}$ & $\begin{array}{r}\$ 0.10 \\
.16 \\
.22 \\
.28 \\
.34 \\
.40 \\
.46 \\
.52 \\
.58 \\
.64 \\
.70 \\
.76 \\
.82 \\
.88 \\
.94 \\
1.00 \\
1.06 \\
1.12 \\
1.18 \\
1.24\end{array}$ \\
\hline
\end{tabular}

Seeds, bulbs and plants up to and including $4 \mathrm{oz}$. in weight can be sent at the rate of $1 \mathrm{c}$ an ounce regardless of distance. Over $4 \mathrm{oz}$. at the zone rate.

Limit of weight for dellvery within iocal first and second zones, 70 pounds; to all other zones, 50 pounds. If weight exceeds this we will pack in 2 or 3 parcels (or more) provided money is remitted to cever postage.

A fraction of a pound is considered a full pound.

$\$ .02$ additional carrying charge.

Low Prices.-A matter of primary importance in buying seeds is to obtain only the best. Our position enables us to supply you with such seeds, and at prices to compete with all reliable seedsmen.

Good Order.- If seeds are not received in good order within a reasonable time, write us and we will look up the shipment. Small orders are of ten delayed in transit.

Cash.-Money must always accompany the order. Money may be sent safely either by Postoffice Order, Express Order or Bank Draft. We will be responsible for the safe receipt of remittances sent by either of the above methods, and in ordersamounting to $\$ 1.00$ or more the cost of remitting may be selected in extra seeds. We accept postage stamps the same as cash.

\section{WARRANTY AND QUALITY OF SEEDS.}

While we exercise the greatest care to have all our seeds Pure, Reliable, and True to Name, we do not give any warranty, express or implied, as to description, quality, and productiveness, or any other matter, of any seeds we send out, and we will not be in any way responsible for the crop. If the purchaser does not accept the seeds on these terms, they are at once to be returned and the money that has been paid for same will be refunded.

Postage.-Postage is not charged on ounces and quarter pounds of vegetable seeds excepting beans, peas and corn. For Parcel Post Rates see front page. 


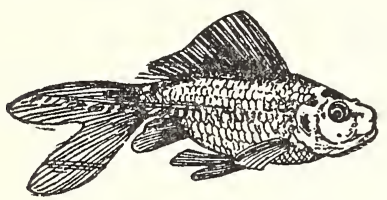

GOLD FISH.

We have an elegant stock of selected American bred fish. 10 cents up. Special prices on quantities.

FISH GLOBES.

All sizes, hanging globes. Prices from 25 cents up.

Full line, from 15 cents up, according to size.

\section{AQUARIA ORNAMENTS.}

COMMON FLOWER POTS.

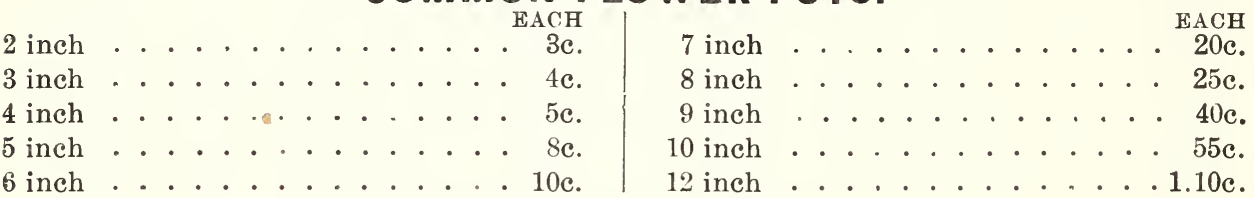

Special prices on large quantities.

Saucers half price of pots.

\section{DRY POWDER SPRAYER-Easy to Operate}

Holds one quart. Price, 75 cents.

\section{THE HICH PRESSURE SINGLE TANK SPRAYER}

It is a marvel. Quick and easy to work. It holds three gallons, and when charged, which takes but half a minute, it will give a continuous spray ten minutes, and will throw a coarse spray 12 to 15 feet high, and a fine stream onto any ordinary fruit tree. Equipped with rubber extension hose, the fine spray can be carried into the tops of trees. This sprayer is especially adapted for tobacco, potato spraying and nursery work.

\section{THE SMITH" "JUNIOR" CONTINUOUS SPRAYER}

Will do anything that any sprayer or atomizer will do and do it three times as fast, with half the labor. It is furnished with two interchangeable brass nozzles, one to spray straight ahead, the other to spray up or down or in any direction.

\section{THE NO. 5 SPRAYER}

Is made of heavy tin with double seamed reservoir, making a strong, indestructible, com pact sprayer. Adapted especially for spraying our Standard Fly and Germ Killer. Holds about one quart.

\section{MARYVILLE BRASS BUCKET OR BARREL SPRAYER WITH AGITATOR}

Complete with hose and graduating fine or coarse spray or solid stream nozzles. PRICES OF SPRAYERS ON APPLICATION.

\section{ASPARAGUS.}

An ounce of seed will sow 50 feet of drill, and produce about 300 plants. Falr crops may be expected the thlrd year from seed.

Columbian Mammoth White Oz. $\quad 1 / 4 \mathrm{lb}$. $\quad$ lb.

Very vigorous and robust in habit; grows large shoots. Needs no earthing up.

Early Giant Argenteuil . . . . . . . . . . . . . . 10 .25 .75

The stalks grow to a mammoth size. It is early, and so very vigor-

ous it is but little troubled with rust.

Washington, Mary

The highest type of the rust-resistant asparagus. It is earlier, larger and longer than the original Washington and quite as resistant. Tips are very tight and do not "sprangle out" or "blow" prematurely. 


\section{BEANS.-Dwarf or Bush.}

\section{Postage:on all Beans to be paid by purchaser. See Parcel Post Rates Front Page}

Beans should not be planted before the ground becomes 1 ght and warm, in favorable seasons usually about the frst of May. The soll should be rich and mellow, and the seeds scattered about 3 inches apart in drills that are 2 to $21 / 2$ feet apart, and covered about 2 inches deep. Successive sowings, made at intervals of about two weeks unth the middle of July, will give a plentiful supply of beans throughout the season. One pound of seed will sow feet of drill.

GREEN PODDED SORTS.

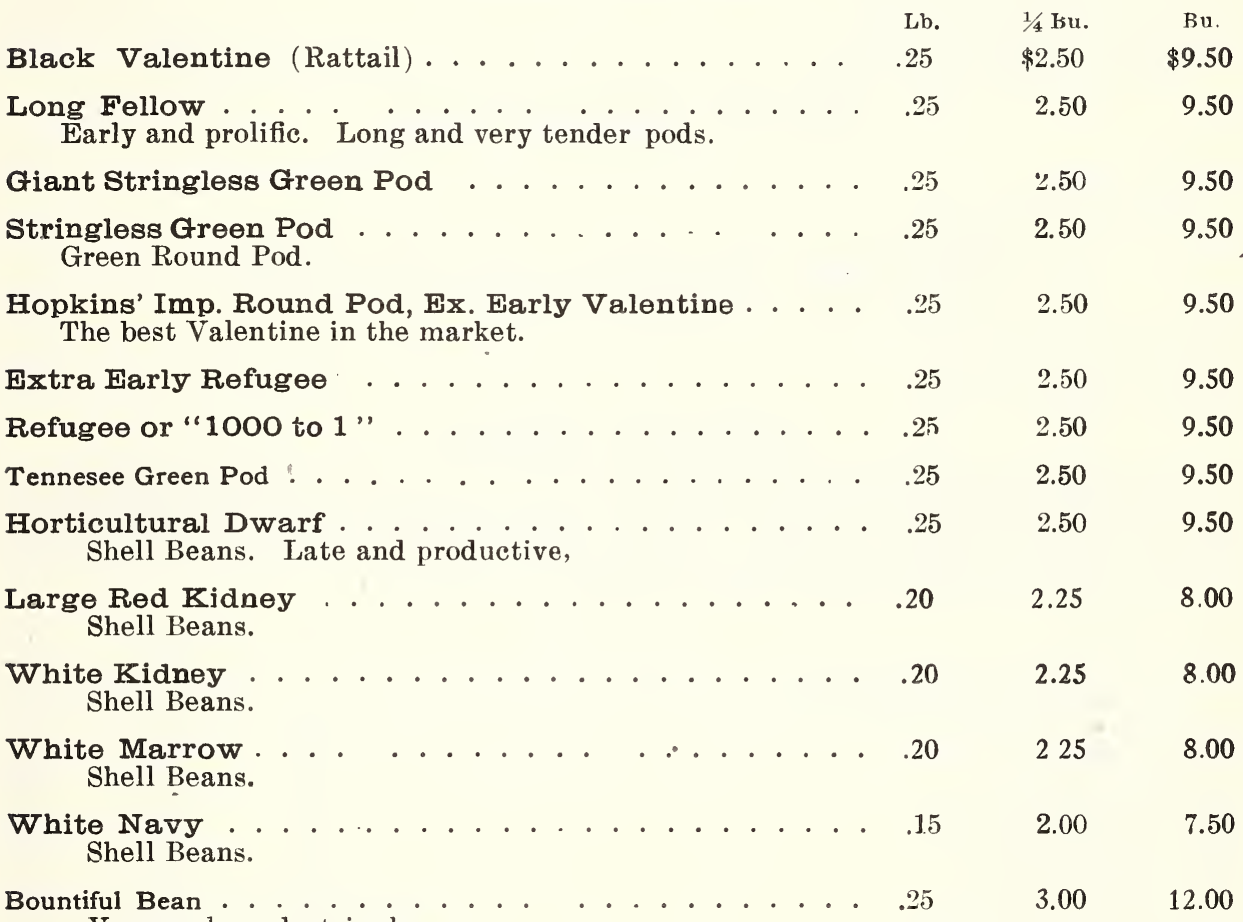

Very early and stringless

\section{WAX PODDED BEANS.}

Wardwell's Kidney Wax . . . . . . . . . . . . . 25

German Black Wax . . . . . . . . . . . . . . . . . ${ }^{25}$

Improved Golden Wax . . . . . . . . . . . . . . .25

Crystal White Wax . . . . . . . . . . . . . . . 


\section{POLE BEANS.}

Less hardy than the Bush Beans, and should be planted several weeks later, when the ground is warmer. Plant the seeds in slightly raised hills 3 or 4 feet apart, 4 or 5 seeds to the hill. The Limas are especially tender, and the rule for late outside planting with them is rigid. Painstaking cultivators, who are usually the most successful, plant them eye downward, after setting stout poles for every hill. All sorts of late-ripening Pole Beans are benefited by pinching the tips of the vines back when they are about 5 feet high. A pound will plant about 100 hills.

Lazy Wife's Lb.

$1 / 4 \mathrm{Bu}$.

Dutch Case Knife

Speckled Cut Short Corn Bean

Horticultural or Cranberry

Kentucky Wonder, or Old Homestead

White Kentucky Wonder

Pods green and tender.

Kentucky Wonder, Wax

Early Golden Cluster Wax

Very early and very prolific.

\section{POLE LIMA BEANS.}

Large Lima

Extra large size.

King of the Garden

\section{BUSH OR DWARF LIMA BEANS.}

Burpee's Imp. Bush Lima and Ford Hook Bush Lima

\section{SWEET CORN.}

Postage to be Paid by Purchaser. See Parcel Post Rates on Front Page.

The Sweet or Sugar varieties being liable to rot in the cold or wet ground, should not be planted before May, or until the ground has become warm, and for a succession continue planting every two weeks, until the middle of July, in rich, well-manured ground in hills three feet apart each way, covering about half an inch and then thin out three plants to a hill, or plant in rows four feet apart and to stand elght inches apart in the rows.

One-quarter pound to 100 feet; 1 gallon to the acre.

Black Mexican

Lb. .15

One of the sweetest and best; ears 8 inches long and 8-rowed;

grains bluish-black when ripe.

Adam's Extra Early

Early Adams

Golden Bantan

Kendall's E. Giant

Early Mammoth

Early Evergreen

Country Gentleman

Shoe Peg

Stowell's Evergreen

Late Mammoth

Howling Mob

Perfection

$1 / 4 \mathrm{Bu}$

$\mathrm{Bu}$

Large eared. early variety.

\section{PEAS.}

Postage to be Paid by Purchaser. See Parcel Post Rates Front Page.

Peas succeed in light, dry, loamy soll. Early and dware sorts require richer soll than the late varieties. If manure is used let it be old and well rotted, or there will be a rank growth of vines with few pods. Sow the early, smooth, round sorts as early in spring as the ground can be worked. Seeds of wrinkled varieties are more liable to rot if the ground is cold and must be planted later. Sow all the varletles quite early and depend for succession upon the different times of ripening of the various sorts, or from the frst sowing sow every two weeks until June for a succession. One-half pound to 100 feet; 2 bushels to the acre.

Big Alaska

Lb.

.25

Alaska

The very ear

Firs qnd Best

Very early.
$\$ 1.25$

1.25

1.25

1.25

1.25

1.50

1.50

1.25

1.25

1.25

1.50

$\$ 4.0$ 
PEAS.-Continued.

Chicago Market

Lb. $\quad 1 / 4 \mathrm{Bu}$.

$\mathrm{Bu}$.

Wrinkled variety; height $1 \frac{1}{2} \mathrm{ft}$; about one week later than

Gradus. Long dark green pods containing 6 to 8 large peas.

Gradus, or Prosperity

One of the earliest of wrinkled varieties; large

pods. Height, $2 \frac{1}{2} \mathrm{ft}$.

Thomas Laxton

Similar to Gradus only a few days later.

Nott's Excelsior

An improvement on American Wonder. Height $1 \mathrm{ft}$.

American Wonder

Well known and very popular. Height, $1 \mathrm{ft}$.

3.00

11.00

McLean's Little Gem
Very prolific; a garder

Very prolific; a garden favorite. Height, $1 \mathrm{ft}$.

10.00

10.00

Improved Stratagem

Pride of the Market

10.00

Very large pods; popular for market. Height, $1 \frac{1}{2} \mathrm{ft}$.

Peter Pan

Wrinkled; long pods containing 7 to 9 peas. Height, $2 \mathrm{ft}$.

Laxtonian

Large, full pods ; fine quality. Height, $1 \frac{1}{2} \mathrm{ft}$.

Telephone

Enormous pods ; fine quality. Height, $4 \frac{1}{2} \mathrm{ft}$.

10.00

Champion of England.

10.00

Well known standard variety. Height, $5 \mathrm{ft}$.

Tall White Marrowfat

Height, $4 \mathrm{ft}$.

Royal Dwarf White Marrowfat

A favorite for market. Height, $2 \frac{1}{2} \mathrm{ft}$.

2.25

\section{BEETS.}

The soll best sulted to the Beet is a deep, light and rich loam. For very early crops, the seed is sown in hotbeds, and the seedlings are transplanted to the open ground. For maln crop, the seed is sown outside as soon as the soll is in good condition, In drills from 12 to 15 Inches apart, and covered about an Inch deep; the plants are thinned to stand 4 or 5 Inches apart in the rows. For winter crops, sow seed in June, in drllls, as for early Beets. An ounce of seed will sow 100 feet of drill; five or six pounds will sow an acre.

Extra Early Dirigo

Oz.

.10

.10

.10

.10

.10

.10

.10

.10

.10

.10

.10

For stock.

Mammoth Long Red For stock.

True Sugar . . . . . . . . . . . . . . . . . . . . . . . . . . . .

Fire Ball . . . . . . . . . . . . . . . . 10

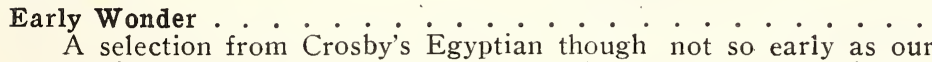
strain of that variety. Roots very uniform, nearly globe-shaped, with small top and tap root; skin dark red, flesh deep blood red, with little zoning. Popular with market gardeners for early or late planting.

$\begin{array}{cc}1 / 4 \mathrm{lb} . & \mathrm{lb} \\ .20 & .60 \\ .20 & .60 \\ .20 & .60 \\ .20 & .60 \\ .20 & .60 \\ .20 & .60 \\ .20 & .60 \\ .20 & .60 \\ .20 & .60 \\ .20 & .60 \\ .20 & .60 \\ & \\ .20 & .60 \\ .25 & .75 \\ .25 & .75\end{array}$




\section{BRUSSELS SPROUTS.}

Dwarf Improved

Species of Cabbage; cultivation the same.

COLLARDS.

True Georgia

Used as Greens.

\section{cabBace.}

Seed sown in hotbed or greenhouse about February 15 wlll glve plants large enough to transplant Into hotbeds about March 10 Set them 2 or 3 inches apart each way, and as soon as they become well established remove the glass for part of the day, to harden them for final trans. planting into the open ground, Increasing the exposure dally untll Aprll 10 or 20, when the final transplanting may be made. Plants for this early crop need not stand further apart than $136 \times 2$ feet. For late crops, sow seeds in Aprll or May, and transplant to the open ground when large enough, setting the plants up to the first leaf, and $2 \times 3$ feet apart. It Is Important that the plants should not stand thlck in the seed-beds, as thls would Induce weak, slender plants. One oz. to 1500 plants; 2 oz. to the acre.

Copenhagen Market

Nearly as early as Wakefield, with solid round heads

Glory of Enkhuizen . . . . . . . . . . . . . . . . . . . . .

Very large; solid round heads.

Extra Early Express

The earliest of all.

Burpee's All Head Early . . . . . . . . . . . . . . . . . . . . . . . . . . .25 Larger than Early Summer and earlier.

Early Jersey Wakefleld.

The standard sort.

Large Charleston Wakefleld .

Very solid and not so pointed.

Early Dwarf Flat Dutch . . . . . . . . . . . . . . . . . .25

Reliable and popular among market gardeners.

Early Winningstadt . . . . . . . . . . . . . . . . . . . . . . . .25 Early; very solid.

Fottler's Early Drumhead A first-rate second early.

Heuderson's Early Spring Extra early ; round flat-heads.

Henderson's Early Summer

One of the best early kinds.

All Seasons. . Fine, large heads.

Henderson's Succession

Similiar to All Seasons.

Burpee's Sure Head

Medium size; round ; very solid and fine grained.

Selected Flat Dutch

A selected strain of large size and a good header.

Late Drumhead

Danish Ballhead

This variety is a true shipper.

Golden Acre

Extra early selection of the Copenhagen type, maturing with Jersey Wakefield

and the earliest of the round head cabbage.

Mammoth Rock Red . . . .

The largest and solidest of all red cabbages.

Improved American Savoy Very fine quality. 


\section{CAULIFLOWER.}

Culture for Caulfilower and cabbages is essentially the same, but to the former extra care given in applying fertllizers and molsture well repays the gardener. Sow the seeds for early and late crops as directed for cabbage, but do not set the early plants in the open fleld too soon, for if too much stunted by severe frosts they begin to form heads before they are strong enough to develop them well. Plants which have not headed berore winter sets in may be stored in a cool cellar or coldframe, and will form heads there without any further attention.

One oz. to 1500 plants; $2 \mathrm{oz}$. to the acre.

Early Snowball Pkt. $1 / 4 \mathrm{Oz} \quad 1 / 2 \mathrm{Oz}$

Early dwarf and reliable.

$.50 \quad 1.00$

\section{CARROT.}

Carrots succeed best on heavy loam, which preferably should have been well fertilized the previous year, as fresh manure often causes the roots to grow pronged and misghapen. Sow the seed as early in the spring as the ground can be prepared, firming the soll down over them.

One ounce of seed will sow 200 feet of drill; 2 pounds will sow an acre.

Roots short and very thick.

Danver's Half Long

Oz. $\quad 1 / 4 \mathrm{lb}, \quad \mathrm{lb}$

Good for all purposes.

Long Orange

Large; good for stock also.

$.10 \quad .25 \quad .75$

\section{CELERIAC.}

Sow in early spring; transplant the seedlings in May. They will be ready for cooking in October and may be preserved in dry sand for use durine winter.

\section{CELERY}

Celery can be grown on any garden soll, but is finest on deep, mellow bottom land. Seed for early crops should be sown in hotbeds about March 15. The plants may either be thinned to give them room to grow, or transplanted to another bed to grow until it is time to plant them in the open ground For main crop, seed should be sown in the open air as soon as the soll and air are warm enough. They should be covered lightly, or merely pressed into the earth with a board if the soll is fine and mellow. The seed-bed must be kept free from weeds, and well watered in dry weather. When the plants are large enough, transplant them to shallow trenches or furrows from 4 to 6 feet apart, according to the variety grown, setting the plante $a$ inches apart in the rows and pressing the soll firmly around them. One oz. to 10,000 plants.

Golden Self Blanching, French Stock . . . . . . . . . . . . . . . . . .50

Winter Queen . . . . . . . . . . . . . . . . . . . .25

Very large stalks; splendid keeper.

White Plume . . . . . . . . . . . . . . . . . . . . . . . . . 25

Celery Cabbage or Chinese Lettuce . . . . . . . . . . . . . . 25

\section{CORN SALAD.}

Sow the seed thickly in shallow drills in September, and firm the soil well down above it, if the weather be dry. Highiy appreciated, and much grown where other salads and lettuces do not succeed. An ounce of seed will sow a bed 20 feet square.

Large Leaf.

Fine for salad.

\section{CRESS.}

One-half ox. to 100 feet of drill.

Used for salad; very pungent.

True Water Cress .

Delicious flavor; very wholesome. 


\section{CUCUMBERS.}

The seed cannot be planted in the open ground before the weather has become warm and settled, and the ground mellow and light. Plant the seeds in well-enriched hills about 4 feet apart each way, and as soon as all danger from insects is over thin the plants to leave four of the strongest in each hill.

One $0 z$. to 50 hills; 1 pound to the acre.

The Davis Perfect Oz.

$1 \mathrm{~b}$.

A sure money maker for those engaged in growing cucum

$30 \quad 1.00$ bers under glass "for profit" as well as for truck gardeners to grow out-of-doors. It is as early as the earliest strain of White Spine and it out-yields by far anything ever tried. Unequaled for quality, shape, color and productiveness. Bound to become the most popular cucumber when known.

Hoermann's Alaska

This is a hybrid sort which produces very fine Cucumbers for slicing or pickling. When suitable for slicing they average from 6 to 8 in. long, uniform in shape, dark green color with lighter stripes extending from the blossom about $\frac{1}{3}$ of the length. Every one should try this variety as it is an abundant yielder and succeeds under conditions where other sorts fail.

"Cumberland"

An excellent new variety; very desirable both for slicing and pickles.

Lemon Cucumber .

A luscious flavored Cucumber. Not same as garden Lemon.

Arlington White Spine . . . . . . . . . . . 10

The old favorite.

Evergreen White Spine . . . . . . . . . . 10

Claimed to be an improvement on the above.

Farly Fortune

Very fine, еэr.y and productive white spine.

\section{Early Cluster}

Chicago Pickling

\section{London Long Green}

West India Gherkin

Good for pickling only. (Small.)

Japanese Climbing

It is suitable for growing either in frames or in the open air. It is very early and exceedingly productive. The fruit is excellent either for table or pickling.

\section{LETTUCE.}

Seed for the first outdoor crop is usually sown in hotbeds in February, and the seedlings transplanted to the garden in April, 8 to 12 inches apart, in rows 12 inches apart. For a succession until frost, sow in drills in the open ground at intervals of every two or three weeks, and thin the plants to stand 6 to 8 inches apart. For plants to force in hotbeds from November until spring, sow seed in hotbeds in the fall, and cover up as winter approaches, untll the plants are required for use. Or the seed may be sown in hotbeds early in winter and the seedlings transwlanted when large enough into fine and well-prepared garden soll.

One-fourth oz. to 100 feet of drill; 2 pounds to the acre.

Grand Rapids.

Extra fine for forcing.

Immensity, extra large size. . . . . . . . . . . . . . . . . . . .15

Black Seeded Simpson

Stands heat well.

Early Curled Simpson

Good for forcing and out doors.

Philadelphia Butter . . . . . . . . . . . . . . . . . . . . . . . . . . . . . . .

Solid heads of large size; stands heat and cold well.

Early White Cabbage or Butter . . . . . . . . . . . . . . . . Large solid heads.

Good header.

Stands drought and hot sun well. 


\section{LETTUCE-Continued.}

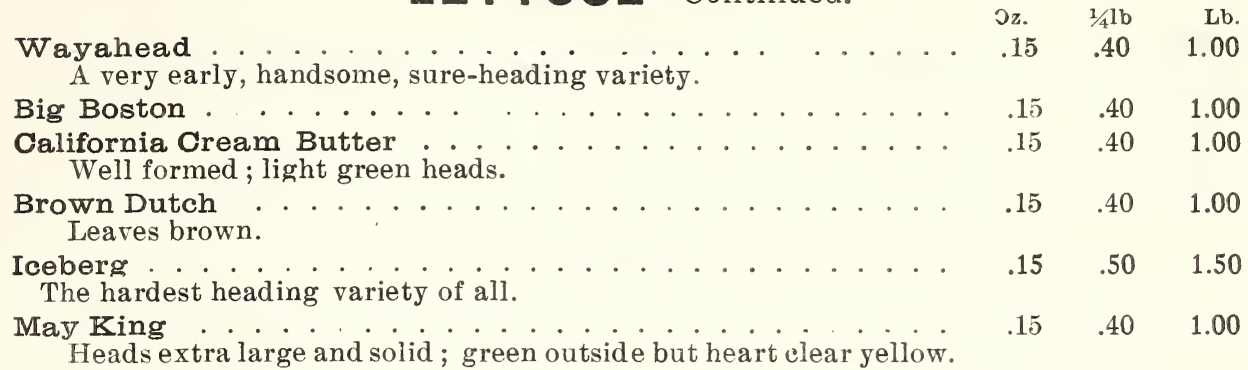

\section{ENDIVE.}

This is an important lall and winter salad. For early, the seed should be sown in April, in drills 15 inches apart, and the seedlings thinned to stand 12 inches apart in the rows Sowings for the main crop may be made in June and July, as the vegetable is used principally in fall and winter. The inner leaves are blanched by tying the tips of the outer ones together, or by laying hoards over the plants. One-fourth oz. to 100 feet of drill.

Broad Leaved Batavian . . . . . . . . . . . . . . . . . . . . . . . . . . . . . . . .

Thick, slightly wrinkled; forming a loose head.

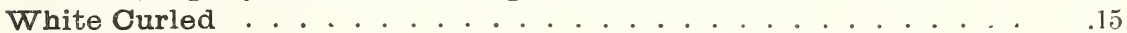

Green Curled . . . . . . . . . . . . . . . . . . . . . . . . . . . . . . . . . . .

\section{EGG PLANT.}

Sow the seed in hotbeds early in March, transplant to small pots and plunge them in the same beds; this is to make them strong and stocky. They should not be planted out until May or June, when the weather becomes warm and settled, as cool nights and wet weather will check their growth. Set the plants in rows 3 feet apart each way and give them thorough cultivation. drawing the earth up to the stems when they are about a foot high. Repeated sowings are sometimes necessary, as the seed does not germinate freely without strong and uniform heat.

One oz. to 2,000 plants.

New York Improved Spineless . . . . . . . . . . . . . . . . . . . . . . . . . . . . . . . .

Black Beauty . . . . . . . . . . . . . . . . . . . . . . . . . . . . 40

\section{KALE.}

One oz. to 2,000 plants, 1 pound to the acre.

Improved Siberian ......... Oz. $\quad 1 / 41 \mathrm{lb} . \quad \mathrm{Lb}$

Dwarf German Green . . . . . . . . . . . . . . . . . . . . $40.10 \quad .25$

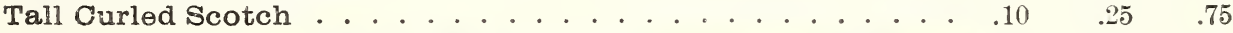

\section{SWISS CHARD, SILVER OR SEA KALE}

Grown exclusively for its leaves, which can be used and served

like Spinach. Cultivation same as for Beets . . . . . . . . . 10

\section{KOHL RABI.}

Very palatable when prepared for the table like turalps. If the weather is favorable the seed should be sown in April, in rows 18 inches apart, and the seedlings thinned to stand a foot apart. One-half oz. to 100 feet of drill.

Early White Vienna . . . . . . . . . . . . . . . . 25

Early Purple Vienna . . . . . . . . . . . . . . . . . . 25

\section{LEEK.}

Used for seasoning soups and bolling with meats. The seed should be sown in hotbeds in early spring, and the seedings transplanted later to the open ground, 8 inches apart, in rows from 12 to 15 inches apart. One-half oz, to 100 feet of drill.

Broad Scotch or London Flag 


\section{MUSTARD.}

The young and tender leaves of the mustard are greatly relished as salads or when cooked like spinach, The seed should be sown in shallow drills as early as the ground can be prepared in spring, and the leaves cut when several inches long. One oz. to 50 feet of drill.

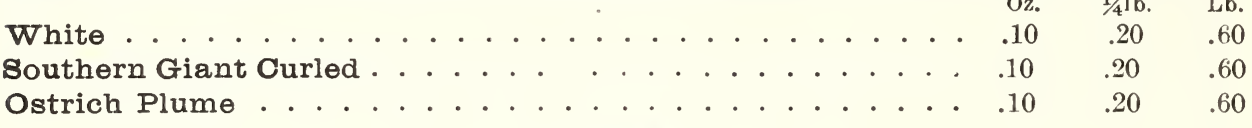

The tender young pods are used for seasoning soups and stews. Sow the seeds thickly in rich soll about the middle of May, in drills 8 feet apart, and cover the seeds an inch deep.

Two oz. to 100 feet of drill.

Dwarf White . . . . . . . . . . . . . . . $10 \quad .25$

Perkins' Mammoth. . . . . . . . . . . . . . . . . . . . . . . $\quad .10 \quad .25$

Green podded; an excellent strain.

\section{ONION.}

Onions thrive best on a rich, deep, loamy soll For sets, the seeds should be sown very thickly in drills as early as possible in spring. In summer, as soon as the tops die down, harvest the bulbs and store them in a dry, cool place, spreading them in thin layers. Early in the following spring replant them 4 inches apart, in small drills 12 inches apart, and they will form into fine, large bulbs early in the season. Large Onions may also be grown from seed the first season if the land is strong and well manured, the seed sown thinly in drills a foot apart, and the seedlings thinned to stand 3 or 4 inches apart in drills; they must be well cultivated and kept free from weeds. Five pounds per acre will be required for large onions; for sets, 25 to 30 pounds. One-half oz. to 100 feet of drill.

Mammoth Prizetaker. . . .

Oz. $\quad 1 / 4$ lb. Lb.

$30 \quad 1.00$

3.00

Largest jellow onion grown.

White Silverskin or Portugal . . . . . . . . . . . . . . . . . . $30 \quad 3000$

Extra Early Red Round . . . . . . . . . . . . . . . . . . . . . $30 \quad 3000$

Extra Large Red Wethersfleld . . . . . . . . . . . . . . . . . . $30 \quad 3000$

Yellow Globe Danvers . . . . . . . . . . . . . . . . . . . . . . . $\quad .301 .00 \quad 3.00$

Southport Large Red Globe . . . . . . . . . . . . . . . . . . . . . . . . $30 \begin{array}{lllll}30 & .00 & 300\end{array}$

Southport Large White Globe . . . . . . . . . . . . . . . . .301 .104 .00

Yellow Danver . . . . . . . . . . . . . . . . . . . . $.30 \quad 1.104 .00$

\section{PARSLEY.}

Much used for garnishing and flavoring soups, stews, etc. The seed is slow to germinate, and should be sown as early as possible, in drills 12 inches apart, thinning plants in rows 4 to 6 Inches apart. One-half oz. to 100 feet of drill.

Plain, for flavoring . . . . . . . . . . . . . . . . . . . 20

Moss Curled. Finely cut and curled for garnishing . . . . . . . . . . . . . 20

\section{MUSKMELON.}

Muskmelon seed should not be planted outdoors until the ground has become warm and dry. The hills should be about 6 feet apart, and carefully prepared. Rich earth is far better for the young plants than manure; but if the latter must be used see that it is well rotted. Plant from six to twelve seeds in $a$ hill, and when the young seedlings are strong enough to re. sist the attacks of insects, thin them, leaving three of the strongest in each hill.

One oz. to 50 bills; 1 to 2 pounds per acre.

Tip Top

Yellow flesh, sweet, juicy and of finest flaror.

Burrell's Gem, or Ordway . . . . . . . . . . . . . . . .10

Oz. $\quad 1 / 4 \mathrm{lb} . \quad 1 \mathrm{~b}$.

$\begin{array}{lll}10 & .30 & 1.00\end{array}$

A yellow fleshed nutmeg, very sweet, and a good seller.

Hoodo or Hearts of Golc

This new variety is the equal of any melon, and superior in its

round qualities. Yellow flesh.

Paul Rose

Very early; good shipper; red flesh.

Emerald Gem

Extra early: orange flesh; very sweet.

Oh o Sugar

Green fleshed, heavily netted. 
MUSKMELON-Continued.

Honey Dew . . . . . . . . . . . . . . . . . . . . . $10^{\mathrm{z} .}{ }_{.30}^{1 / 2 \mathrm{lb}}{ }_{1.00}^{\mathrm{Lb}}$

A new, distinct melon of the Cassaba type. Fruit large ovid in form, about 10 inches long and 8 inches in diameter; surface smooth and hard without ribbing or netting, creamy white in color, turning to a lemon tint when fully ripe; flesh light emerald green, very thick, ripening to the rind, very tender and melting. with an extreme sweetness found in no other melon. Matures with Osage and is an excellent shipping and keeping sort.

Osage

Yellow flesh.

Iron Clad (Eden Gem) . . . . . . . . . . . . . . . .10

One of the very best shipping melons. Green flesh.

Pollock's No. $10-25$

A selection from No. 25, having deeper salmon tint, more uniform in size and better netted. Popular as a shipping melon at Rocky Ford.

Rocky Ford Colorado grown Netted Gem . . . . . . . . . .. 10

Chicago Market $\quad$ A large and excellent green fleshed nutmeg; leading market melon of Chicago.

Extra Early Hackensack . . . . . . . . . . . 10

Blue Ribbon Gem

\section{WATERMELON.}

Secure good strong vines early in the season by making the hills large, mellow and well drained, with the manure placed so that they will not dry out quickly under hot suns. All possible protection from insects should be given the young plants, and as a protection from insects, use dry ashes or coal dust sprinkled over the leaves Plant the seeds thickly, and thin the plants to four of the strongest in each hill.

One oz. to 50 feet of drill; 1 to 2 pounds to the acre.

Kleckley Sweets (Colorado grown)

Oz. $\quad 1 / 4 \mathrm{lb} . \quad$ Lb

The sweetest table melon known.

$.10 \quad .90 \quad .60$

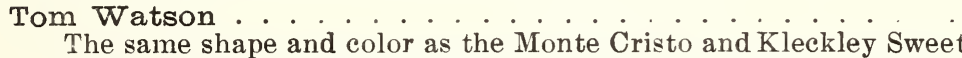

only larger and a better shipper. The skin is of a rich, deep green, the flesh a deep red and very sweet.

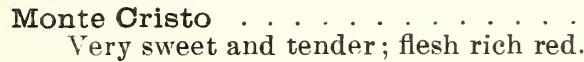

Halbert's Honey . . . . . . . . . . . . . . ${ }^{.} 10$

Excell

Round Dark Icing . . . . . . . . . . . . . . . . . . . 10

Long Light Icing . . . . . . . . . . . . . . .10

Gypsy, or Rattlesnake Irish Grey

\section{PUMPKIN.}

Growi princlpally for stock-feeding, yet some are so sweet, Julcy and fine-grained that they will always be considered indispensable for ples and sauces. The vines require the same culture as that recommended for melons, but the seeds must be planted in hills much wider apart; irequently they are planted among corn. A pound of seed will plant from 200 to 300 hills.

One to two pounds to the acre.

Sweet Cheese or Kentucky Field

The best sort.

Cusıaw and striped Cushaw . . . . . . . . . . . . . . . ${ }^{10}$

Long, yellow, crookneck; fine for table or stock. 


\section{POP CORN.}

\section{PEPPER.}

Sow in hotbed as early as Aprll, and transplant to rich, warm, mellow soll, as soon as the weather has become warm and settled, setting them about 2 feet apart in drills 3 feet apart.

nile oz. to 1,500 plants.

Ruby Giant, and Ghinese Giant.

Largest of all. Red.

Sweet Mountain . . . . . . . . . . . . . . . . . .

Large; square shaped and mild.

Bell or Bull Nose

Not quite so mild as Sweet Mountain.

Ruby King

Fruit very large; bright red color. Very mild.

Cayenne

Fruit long, hot and pungent.

Red Chili

Small and prolific. Used for pepper sauce.

Pimento

\section{PARSNIP.}

Sow the seed in drills 15 inches apart, as early as possible in spring, and thin the plants until they are 5 or 6 inches apart in the rows. The roots are much improved by frost; to be dug up as required. On the approach of cold weather, cover them heavily with manure or litter. Deep, rich, heavy soll is best sulted to the culture of Parsnips, and the roots will be smooth and large if no fresh manure is used; as this tends to make them coarse-grained and misshapen.

One-half oz. to 50 feet of drill; 3 pounds to the acre.

Large Hollow-crown Sugar

Oz. $\quad 1 / 4$ th $\quad$ Lb.

$.10 \quad .25 \quad .75$

\section{PEANUT.}

Make rows two or more feet apart, and drop seed eight inches apart. Matures very early, and may be planted after oats in July. In gathering every pea comes out.

Virginia

\section{RADISH.}

Sow in sheltered spot, the earth being deeply dug, highly fertilized, and raked free from clods and stones. Radishes grown on poor, thin soll cannot be made good; they will be misshapen and tough. To be good they must be grown quickly Radishes can be forced by covering with a window or a sash. One oz, to 100 feet of drill; 10 to 15 porsds per acre.

Icicle.

$.10 \quad .30 \quad 1.00$

Long, smooth, white forcing radish.

Carmine Forcing

The best and quickest early scarlet turnip radish.

Scarlet Globe

Fine for forcing and open ground; very early.

Crimson Giant Extremely large but never pithy; suitable for forcing or open cul-

tivation; tender and crisp. 


\section{RA DISH-Continued.}

Wood's Early Frame

$1 / 4 \mathrm{lb}$. Lb.

Early Long Scarlet Short Top . . . . . . . . . . . . . . . . . . $.10 \quad .25 \quad .75$

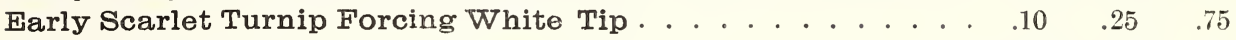

Early White Turnip . . . . . . . . . . . . . . . . . . . . . . . . . . . . . . . . . . . . . . . . . .

French Breakfast. . . . . . . . . . . . . . . . . . . . . . . . . . . $10 \quad .25 \quad .75$

Golden Globe . . . . . . . . . . . . . . . . . . . . . . . . . . . $10 \quad .25 \quad .75$

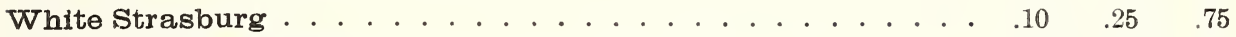

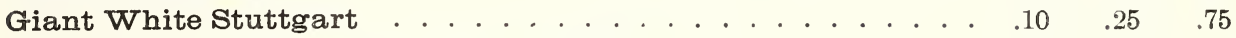

White Lady Finger, or Long White Vienna . • . . . . . . . . . . .10 .25 .75

Celestial, or White Chinese . . . . . . . . . . . . . . . . . . . . $.10 \quad .30$

Best for fall; very large white radish.

California Mammoth Winter . . . . . . . . . . . . . . . . . . . $.10 \quad .30$

China Rose Winter . . . . . . . . . . . . . . . . . . . . . . . . . . . . . . . . . . . . . . .

Long Black Spanish Winter . . . . . . . . . . . . . . . . . . . $.10 \quad .30$

Round Black Spanish Winter . . . . . . . . . . . . . . . . . . . $.10 \quad .30$

Sparkler . . . . . . . . . . . . . . . . . . . . . . . $10 \quad .30$

\section{RHUBARB.}

Sow the seed early, and when the plants are large enough thin them to 4 or 5 inches apart. The next spring or fall transplant them 3 feet apart each way in deep, rich soll. For forcing. take up some large roots and place them in a dark corner of the cellar or greenhouse.

Two oz. to 100 feet of drill.

Victoria

$\begin{array}{lr}\text { Oz. } & 1 / 4 \mathrm{BD} \\ .10 & .30\end{array}$

\section{SEED SWEET POTATOES.}

The stock is of suitable size for bedding-small to medium (none very small). Always sorted before we ship same, so that nothing but sound stock can be sent out But we wish it distinctly understood that customers take all risks after we deliver in good condition to the express or railroad company here. We do not ship until planting time (About April 10.)

Extra Early Carolina.

Early Yellow Jersey.

Market prices.

\section{SALSIFY, OR OYSTER PLANT.}

When cooked, the roots have something of the flavor and odor of oysters. They may be bolled, used in soups, or grated and fried as iritters. Culture the same as for parsnips and carrots. Roots are perfectly hardy, and may be left in the ground all winter. A quantity of roots for winter use may be stored in a pit or in sand or damp earth in a cellar.

One oz. to 100 feet of drill.

Mammoth Sandwich Island.

Oz. $\quad 2 / 4 \mathrm{tb}$

$.20 \quad .70$

\section{SPINACH.}

One of the most Important crops grown for greens, and may be had in good conditon from very early in the spring until cold weather. For early use sow very early in spring, and for succession at intervals. The main crop for spring and winter use should be sown in September and the plants covered for winter. One-half oz. to 100 feet of drill; 6 to 8 pounds to the acre.

Bloomsdale Savoy . . . . . . . . . . . . . . . . . . . . . . . . . .

King of Denmark. New . . . . . . . . . . . . . . . . $10 \quad .20 \quad .50$ 


\section{SQUASH.}

Seed should not be planted in spring until all danger of frost is past. Plant in hills 5 feet apart for bush varietles and 6 to 8 feet apart for running sorts, putting 6 to 8 seeds to the hill, finally leaving but 3 plants. One-half pound to 200 or 300 hills; 2 to 3 pounds per acre.

Early White Bush

Oz. $\quad 1 / 4^{\text {th }}$

$.10 \quad 25$

Early; flat scallop shape.

Summer Crook-Neck . . . . . . . . . . . . . . . . ${ }^{10}$

Fruit about one foot long with crooked neck.

Warty Hubbard . . . . . . . . . . . . . . . . . . . . . . .

A Hubbard squash completely covered with warts.

A fall and winter variety.

Golden Hubbard

Boston Marrow, similar to Hubbard . . . . . . . . . . . . . . . . . . .15

Banna Squash

\section{TURNIP.}

For early, sow as soon as the ground can be prepared, in drills 15 inches apart, and thin the plants to stand 8 inches apart. Sow for succession at intervals of two weeks until the last week in July, and from that time onward until the last of August sow for main crop. The sowings should always be made just before a rain, if possible, as the success of the crop depends, in a great measure, upon quick germination and rapid growth of the young plants.

One oz. to 300 feet of drill; 1 pound to the acre.

Extra Early White Milan

Early Purple Top Milan.

$.10 \quad .25$

Red, or Purple Top Strap Leaf . . . . . . . . . . . . . . . . . . .10

Red Top White Globe . . . . . . . . . . . . . . . . . . . . ${ }^{10}$

White Flat Dutch

White Globe

Golden Ball

Excellent for table or stock: flesh yellow and sweet.

Cow Horn

Grown for stock.

\section{TOMATO.}

As the plants advance in growth support them by brushwood. To have the Tomato very early it is necessary to start the plants in a hotbed, or they may be reared in a flower pot in a window and subsequently transplanted. Plants for an early crop should be raised under glass. For intermediate crop they may be raised on outside beds. For late crops the seed may be planted in permanent position. One oz. to 2,500 plants; 2 oz. to the acre.

Ponderosa.

Oz. $1 / 4$ to

The largest tomato grown; rich crimson; solid flesh.

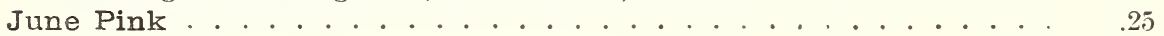

Red Head (New) . . . . . . . . . . . . . . Toptown

An exceptionally fine, large, bright red variety, as early as Chalk's Jewell and nearly as large as Stone and as productive; fruits nearly globe-shaped, very solid; vine of medium growth; an excellent canning variety.

Spark's Earliana

Very early; bright red, smooth and of good size and excellent flavor.

Dwarf Champion

Very early; dark purplish red.

Livingston's Perfection

Early; medium size; color blood red.

A very early, large red variety of fine quality. 
TOMATO-Continued.

Early Detroit .

Very early; vigorous and productive; color scarlet. . . . . . 25

Livingston's Beauty .......

Well known variety; crimson, tinged with purple.

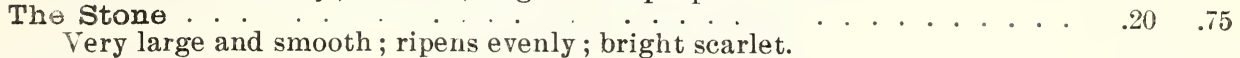

Dwarf Stone

Chalk's Early Jewel . . . . . . . . . . . . . . . . . . . . $25 \quad .85$

Very early; smooth, round and of superior quality.
Red Rock

very smooth.

Greater Baltimore

Large as Stone; deep red, very solid and productive.

Golden Queen

Yellow; ripens early; is large size, smooth and solid.

Yellow Pear

Used for Preserves.

Red Pear

Used for Freserves.

Marglobe

This new main-crop or midseason tomato is a wilt-resistant variety bred for use in disease infected districts. In addition to being wilt-resistant, it is a handsome deep red globe shaped tomato of great merit. The plants are vigorous and productive and the fruits are quite large. In our trials they averaged $7 \frac{1}{2}$ ounces in weight. The flavor seems to be a happy medium between the acid and non-acid sorts. The shape and size of the fruits makes this a very desirable salad or slicing tomato and the color and quality seem ideally fitted for canning.

\section{TOBACCO.}

Sow the seed in plant bed in March. Transplant when five or six leaves appear. Set in rows $3 \frac{1 / 2}{2}$ feet apart, 18 to 30 inches apart in the row, according to variety. When the bud appears, break off the top, leaving 16 leaves to mature. Keep off all suckers growing from the stem. When the leaves have become waxy and brittle it is ripe. Cut and hang the stock in a shed to dry.

Ccnnecticut Seed Lea

Well-known variety.

White Burley

Havana

Caraway-Seeds used for flavoring

\section{HERBS}

Coriander-Seeds used for flavoring

Dill-Used for flavoring Pickles

Sweet Marjoram-Used as a seasoning

Rosemary-Leaves very fragrant

Sage-A highly aromatic Herb, most useful of all

Thyme-Used as a seasoning

Savory, Summer-Used as a seasoning

Savory, Winter-Used as a seasoning

Sorrel-Large leaved, French-Used as a Salad or cooked as Greens

Basil-Sweet-Leaves used for flavoring . . . .

Chervil-Used for flavoring Soups

Chicory-Large rooted-The dried leaves are roasted and mixed with Coffee or used as a substitute

\section{Aspargus Roots? \\ Rhubarb Roots Prices on application.}

\section{PRICES SUBJECT TO CHANGE WITHOUT NOTICE.}




\title{
Farm Seeds.
}

\author{
FIELD CORN. \\ Prices and Kinds on Application.) \\ GRASS SEEDS.
}

(Prices of all Grass Seeds vary and can not be quoted.)

Timothy. Prime quality always in stock.

Kentucky Blue Grass and Red Top.

Orchard Grass. A very valuable grass, and should be extensively used for pasture, and is also good for hay.

Soudan Grass. The great rain and drought resister; the coming hay and fodder crop. Will produce a crop in four months. 15 to 20 pound will sow an acre.

\section{CLOVER.}

Medium, or Common Red; Mammoth or Large English; White, Alsike, Crimson, or Scarlet, and Alfalfa.

Whito and Yellow Blossom Sweet Clover. Used for innoculating land for alfalfa also excellent for bee culture.

Prices of the above cannot be quoted here, as they will vary.

Hubam Sweet Clover

\section{SOUTHERN COW PEAS.}

The Great Land Renovator. The Growing Crop Not Oniy Enriches the Ground, but Furnishes a'Large Amount of Most Valuable Forage

For Dry or Green Feeding.

Sow from $1 \frac{1}{4}$ to $1 \frac{1}{2}$ Bushels to the Acre.

Whip-poor-Will. An early variety, tall, upright; medium yield of vines ; large yield of peas, for which they are particularly grown. Highly recommended for "hogging down." Market price.

Canada Field Peas. Market price.

Dwarf Essex Rape. A forage plant of highest value. It can be sown in April for an early crop, and for fall crop in July, August and September, and still later further South. It is sown broadcast 6 pounds to the acre, but it is better drilled, in which case 4 , pounds to the acre will suffice. In a few weeks from the time of sowing sheep, hogs or cattle can be turned on it. All reports agree that thes gain weight faster on this than any other fodder. As it can be sown after other crops are off, the gain in fodder is secured at a nominal cost. Stockmen, dairymen and farmers have proved its value.

\section{BUCKWHEAT.}

Should be sown about the middle of June, broadcast, using from one-half bushel to three pecks of seed to the acre.

Japanese. This new sort has proven to be much earlier and more productive than any other variety. The grains are very large and of a rich brown color. It excels in yield and earliness. Market price.

Common. The well known sort. Market price.

\section{SORGHUM, OR SUGAR CANE.}

Sorghum is being used extensively as a green food for cattle, horses and mules. It is a sure crop, being a great drought resister and immense yielder, producing many tons of most nutritious green food to the acre. Specially fine for food for milk cows when pasture is short.

Early Orange Cane. A strong grower; much more juicy than any other variety. The stalk is heavier, and a litile later than the Amber. Market price.

Early Amber Cane. Earliest of all. Market price.

BROOM CORN-Improved Fvergreen. The best for general cultivation. Brush firm, of good length and bright green color. Market price. 
AMOUNT OF FIELD SEED REQUIRED TO THE ACRE.

Clover, common red, 8 to $10 \mathrm{lbs}$. per acre.

Clover, Alsike, 5 to 6 lbs. per acre

Alfalfa, 15 to $20 \mathrm{lbs}$. per acre.

Clover, sweet, 15 to 20 lbs. per acre.

Timothy, 6 to $8 \mathrm{lbs}$. per acre.

Blue Grass, 15 to 25 lbs. per acre.

Orchard Grass, 15 to $20 \mathrm{lbs}$. per acre.

Red Top, hulled, 8 to 10 lbs, per acre.

Red Top, unhulled, 20 to 25 lbs. per acre.

Sudan Grass, 15 to 20 lbs., broadcast per acre.

Buckwheat, 35 to 40 lbs. per acre.

Corn (field), 6 to $8 \mathrm{lbs}$. per acre.

Millet, 1 to $11 / 2$ bushels per acre.

Cow Peas, 1 to $11 / 2$ bushels per acre.

Rape, 6 to 8 lbs. per acre.

Cane, in drills 6 to $8 \mathrm{lbs}$; ; broadcast, 25 to

30 lbs. per acre.

Rye, 1 to $11 / 2$ bushels per acre.

THE CYCLONE SEED SOWER. The best on the market.

\section{HOW TO MAKE A LAWN.}

The ground should be spaded deeply and thoroughly raked to a level and fineness, and after the seed is sown should be very lightly raked, as heavy raking would cover it too deep. After raking it is well to roll it, but it is not absolutely necessary.

Rentucky Blue Grass is largely used alone, and it makes a fine sod. It is well to use with it a little White Clover, which is of low growth and looks well, and it is of surer growth than blue grass. As light seeds like blue grass cannot be covered deep, but must be close to the surface, they are readily affected by dry weather. The seed may be ready to sprout and in the morning be moist, but before night be dried out and ruined. With this uncertainty it is well to sow a little Red Top with it, which is of much surer growth, and in a couple of years the blue grass will run it out.

Seed can be sown with good results almost any time where water can be had to sprinkle when it becomes dry. If not, then February and March are the best months, that it may come up with the warm spring rains. August and September are also good months, as we usually have fall rains to do the same.

It is advised to sow one pound of seed to each 15 feet square on bare ground, and on old lawns in proportion as needed.

Choice Blue Grass White Clover Red Top

Evergreen Lawn Grass Seed, a mixture of the best grasses,

Shady Nook Grass Seed

\section{NEW PLANT LIFE ODORLESS LIQUID FERTILIZER Contains Potash, Nitrogen and Phosphoric Acid}

Supplying the needed nourishment for House Plants, Lawns, Shrubbery, Flowers, Veget able Gardens and Trees. One pint will make 20 gallons of Fertilizer.

New Plant Life free from weed seeds, and does not deteriorate.

PULVERIZED SHEEP MANURE-Much better and less objectionable than barn yard manure.

INCREASE YOUR YIELD OF ALFALFA, CLOVERS, COW PEAS and other Legumes by Inoculating Your Seed or Soil with

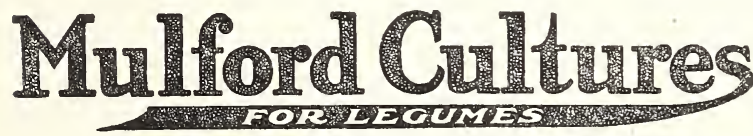

Mulford Cultures improve your soil and, when properly used under favorable conditions, induce a prompt "catch" and of ten more than double your yield. They are easily used by anyone, without previous experience. No special knowledge or implements are required. Supplied in :

$2 \frac{1}{2} \mathrm{Bu}$. Size

$1 \mathrm{Bu}$. Size 1.00

Small Size (supplied only in 4 varieties, for Garden

Peas,Garden Beans, Lima Beans and Sweet Peas) .35

Always specify on your order what crop you want o inoculate, as there is a different strain of bacteria or each legume.

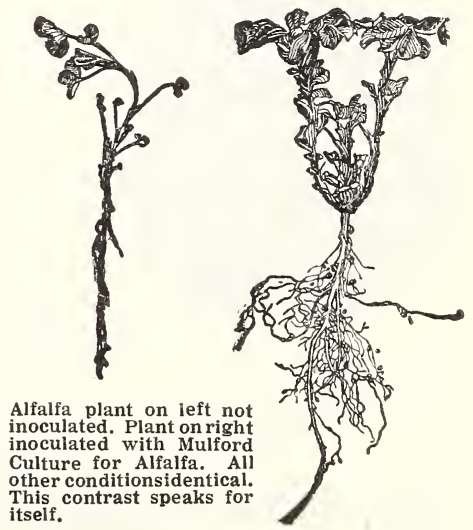




\section{Supplies for Horses, Cattle, Hogs and Poultry.}

\section{LINSEED MEAL.}

(Crushed Oil Cake. Old Process.)

Well known as an excellent food. Market price.

SALT-LODE-For Horses, Cattle, Hogs and Poultry.

This new preparation is used by mixing 1 pound salt-lode with 5 to 10 pounds barrel salt. 10 pound bucket $\$ 1.00$; half pound trial package $10 \mathrm{c}$ postpaid.

\section{PRATT'S POULTRY AND STOCK REMEDIES.}

Hog Cholera Specific, Animal Regulator, Conditioner, Poultry Regulator, Lce Killer, Roup Cure, Worm Powder for stock, Chicken Cholera Remedy, Sore Head Chicken Pox Remedy, Animal Dip, Gape Remedy, Healing Powder, Head Lice Ointment, Healing Ointment. Scaly Leg Remedy, Foultry Disinfectant, Heave Cure, Baby Chick Food, Cow Remedy, White Diarrhoea Remedy, Colic Remedy, Distemper Remedy, Poultry Condition Tablets, Bronchitis Remedy, Veterinary Liniment, Chick Starter.

\section{LEE'S POULTRY REMEDIES.}

Lice Powder, Liquid Lice, Egg Maker, Chick Grower and Germozone.

\section{CONKEY'S POULTRY AND STOCK REMEDIES.}

Lice Powder, Stock Tonic, Poultry Tonic, Nox-i-cide Disinfectant, Roup Cure Worm Remedy, Cholera Cure, Scaly Leg Remedy, Gape Remedy, Sore Head Remedy, Head Tice Ointment, Limber Neck Remedy, Lice Iiquid, Heave Cure, Chick Starter.

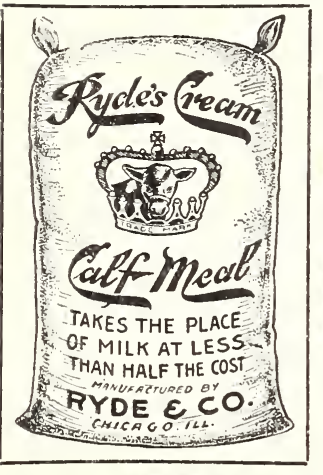

\section{CULTURES} Humogerm 1 Acre Size

$\$ 1.00$ $\$ 4.50$ Nitragin 66 5 " " 1 Bu. 5 แs

66 $\$ 1.00$ $\$ 4.50$

D ON SUNG. CHINESE EGC LAYING TABLETS

A New Discovery. Price 50 cents per box of 30 Tablets; large box of 90 Tablets $\$ 1.00$. Poultry raisers all over the United States say Don Sung makes hens lay.

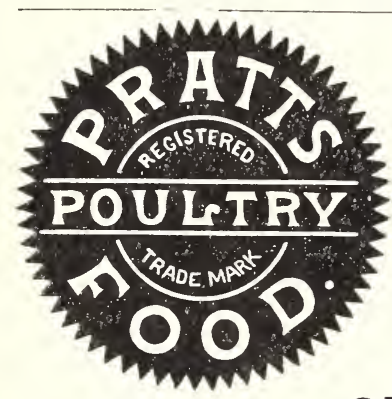

SPRATT'S REMEDIES.

Spratt's Dug Uakes.

" $\quad$ Puppy Cakes.

" Puppy and Dog Vermifuge Spratt's Patent Fish Food.

Ground Oyster Shell-Will increase the supply of eggs and keep poultry in healthy condition.

Hoermann's Louse Killer-For poultry and stock. LICE KILLING NEST EGGS.

Sunflower Seed-Large Russian. Sunflower seeds are superior food for poultry (said to improve the meat). Special prices in quantities.

Spratt's Cod Liver Oil Cakes.

" Cat Food

“ Charcoal Cakes.

MALTOID-MILK-BONE. Bone Shaped Dog and Puppy Cakes. RYDE'S CREAM CALF MEAL. 


\section{SERGEANTS DOG REMEDIES.}

Mange Medicine Distemper Medicine
Pepsin Tablets Arsenic \& Iron Pills
Condition Pills

Skip Flea Powder

\section{PIGEON FEED.}

Hem Seed.

Canadian Field Peas.

Kaffir Corn.

Pigeon Grit.

\section{HAMMOND'S SLUG SHOT}

HAMMOND'S SLUG SHOT, one of the best vegetable insecticides in use. Specially recommended for destroying the Cabbage worm, Potato bug, Tobacco worm, and other insects that prey on vegetation. Gardeners need have no fear about applying this, as it is not dangerous to handle like Paris Green, etc. Non-poisonous to human life. The quantity used per acre varies from 10 to 40 pounds, according to the size and number of plants.

CARBOLINEUM.

Wood Preserving Disinfectant . . . . . . . . . . . . 1 Gal. Size $\$ 1.50$ 5 “ “ $\$ 6.00$

Spray Your Flowers, Shrubs, Fruits, Vegetables, Etc., with "BLACK LEAF 40"

Destroys such insects as Aphis (Plant Lice) Thrips and Leaf Hoppers. Contains $40 \%$ of nicotine. $1 \mathrm{oz}$. makes about six gallons of spray.

Price 35c, $\quad 1 / 2 \mathrm{Lb}$. Can, $\$ 1.25$

"Nico-Fume" for Spraying and Fumigating in Greenhouses

"NICO-FUME" LIQUID

"Nico-Fume" Liquid is a highly refined solution of free nicotine and is of exceptional purity. It is guaranteed to contain $40 \%$ of nicotine by weight in water solution. It contains no alcohol, camphor or other chemicals or adulterants which might impair its efficiency or injure plants, and is especially well adapted to florists' general needs, both for fumigation and spraying purposes.

$\frac{1}{4}-1 \mathrm{~b}$. tin, price $75 \mathrm{c}$, contains at least 700 grains of pure nicotine.

$1-1 b$. tin, price, $\$ 2.25$ contains at least 2800 grains of pure nicotine.

CARBOLA Germ Killing White Paint. Use it instead of white wash and disinfectants

Lime and Sulphur. Fungi Bordo. Bordeaux Mixture. Paris Green. Slug Shot
Whale Oil Soap. $\quad$ Sulpho Tobacco Soap. (Prices on Application.)

\section{POULTRY SUPPLIES}

Poultry Markers, Chick Starter, Poultry Leg Bands, Scratch Feed, Charcoal, Alfalfa Meal, Beef Scraps, Drinking Fountains, Fine and Coarse Grit, Chicken Feeders, Oyster Shell, Meat Mash

(Prices on Application). 


\section{FLOWER SEEDS.}

\section{ALYSSUM.}

One of the sweetest and most useful of summer flowers. Hardy annual.

$\$$ \$weet. Flowers pure white. Five cents per packet.

\section{ANTIRRHYNUM.}

(Snapd ragon.)

One of our most showy and useful border plants. Hardy; blooming ${ }^{*}$ the first year from seed. One or two feet.

Finest Mixed. Per packet, 5 cents.

\section{ASTERS.}

Give the Aster a deep, rich soil, and a mulching of coarse manure is very beneficial. A little liquid manure occasionally will give good results. Sow early in the house, and transplant into pots or boxes. As soon as the weather is warm enough plant in beds about twelve inches apart. Half-hardy annuals.

Semple's Branching. A beautifu strain of late flowering Aster, which bears on long stems, perfectly formed double flowers 4 inches in diameter, 18 inches to 2 feet high. Double mixed. Pkt. 10c.

Giant Comet. A beautiful and distinct class. Their very large, double flowers are often 4 to 5 inches across, with long, surled and twisted petals, forming loose half-globes, resembling Japanese Chrysanthemums.

Separate colors-white, pink, purple; packet 10.

Mixed colors; packet 10 cents.

Queen of the Market. A first-class early flowering Aster. coming into fiower in July, of branching habit; flowers of good size and borne on long stems, making them exceedingly valuable for cutting; one foot. Per packet, $5 \mathrm{c}$. .

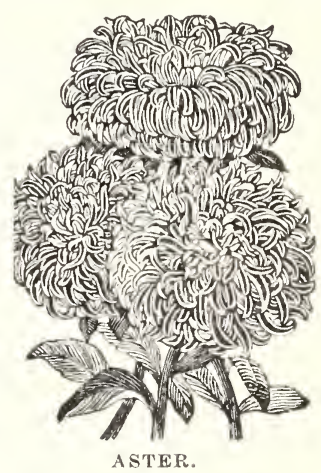

\section{ACERATUM or Floss Flower.}

One of the very best bedding plants. Packet, 5 cents.

\section{AMARANTHUS (Joseph's Coat.)}

Ornamental foliage plants. Per packet, 5 cents.

\section{BALSAM.}

(Lady Slipper or Touch-Me-Not.)

Desirable for garden or pot culture. The soil should be of the richest and best quality Set them about fifteen inches apart, and give them plenty of manure water. Tender annuals. Two feet.

Double Camellia Flowered Mixed. Of perfect form; beautiful colors. Per packet, 5 cents.

\section{CENTUREA.}

Special Callfornia Strain. All colors. Very fine. Small trial packet 5c.

Bachelor's Button. This is the widely known and ever popular Corn Flower, or Corn Bottle. Hardy annual. Two to three feet high. Packet, š cents.

\section{CANDYTUFT.}

A well known favorite. Is a hardy annual, very pretty in beds or masses

White. One foot. Packet, 5 cents.

Mixed colors. One foot. Packet, 5 cents.

\section{CALENDULA (Pot Marigold.)}

Showy, free-growing hardy annuals; valuable also for pot culture; 1 foot. Packet 5c. 


\section{CALLIOPSIS.}

Very handsome and showy plants, with numerous flowers of brilliant colors and of long duration in bloom. Of the easiest culture.

Mixed. All colors. Packet, 5 cents.

\section{CARNATION.}

Carnations are general favorites for their delicious fragrance and richness of colors, Protect during the winter. Half-hardy perennial. One and onehalf feet.

Fine Double Mixed. The hardiest and best varieties for garden culture. Packet, 10 cents.

Marguerite. These are deservedly the most popular Carnation with the amateur, as they begin flowering in a few weeks from time of sowing. Finest mixed. Packet, 10 cents.

\section{CANNAS.}

Soak the seed for twelve hours in warm water before planting, and keep in a warm spot. The roots can be kept in the cellar over winter. The mixed seed we offer has been saved from the finest varieties of all colors. Packet, 5 cents.

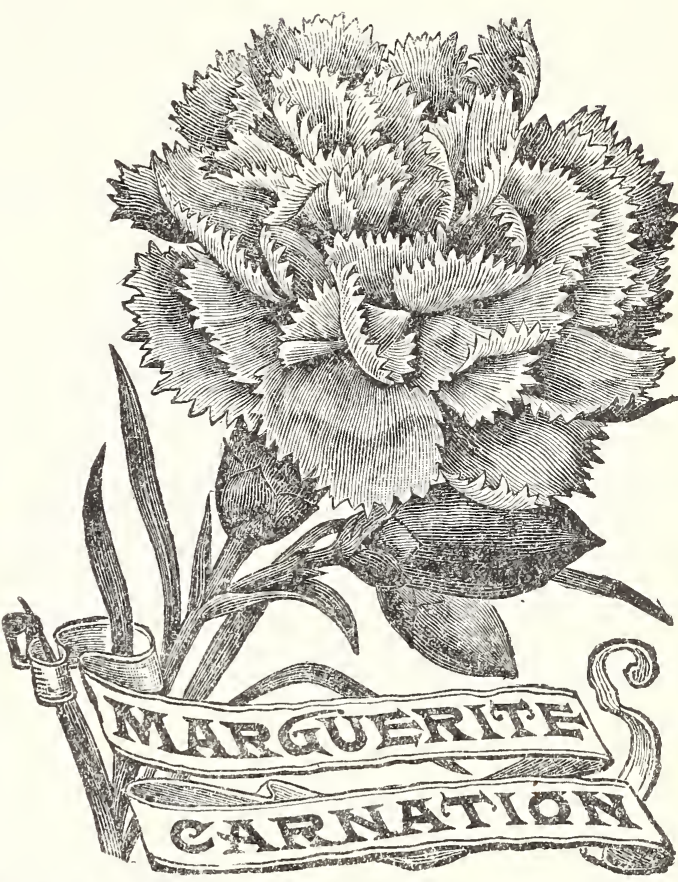

\section{CANTERBURY BELLS.}

Very ornamental growing about 2 ieet high; large bell-shaped flowers. Packet, 5 cents. CASTOOR EEANS.

Castor Bean, in all its varieties, has a very showy tropical appearance, singly or in groups. Mixed Colors. Packet, 5 cents.

\section{CENTENMALL PLANT (Mexican Fire Bush.)}

A very ornamental plant for borders and rookeries, producing fern like trees from 1 to 2 feet high. Of easy culture and very hardy. Packet, 5 cents.

\section{CHRYSANTHEMUM.}

The annual varieties are hardy, very pretty, especially when grown in masses. Easy eulture; stand the heat; require rich soil.

Coronarium. Mixed colors. One foot. Packet, 10 cents.

\section{COCKSCOMB.}

The Cockscombs are tender annuals, require rich soil, will attain rich color and large size by repeated shifting; cut off side flowers and leave one head only to a plant. If cut before they fade the head may be preserved during the winter.

Mixed Colors. Packet, 5 cents.

\section{CHINESE WOOLFLOWER.}

This new Cockscomb is one of the most magnificent garden annuals ever introduced. Plants grow two or three feet high, the bloom starting early with a central head, round and globular, which often reaches an immense size. Scores of branches are thrown out, each bearing a ball of scarlet wool, but not so large as the central one. None of the blooms fade in any way until hit by frost.

Start seed if convenient under glass about four weeks before time to transplant to the garden. If the little plants remain too long in pots or seed beds, they will begin to set bloom, which is not desirable. Transplant to the garden as soon as danger from frost is passed. Per packet, 5 cents. 


\section{COLUMBINE. (Aquilegia.)}

No hardy plant is more easily grown than the Columbine. Seed may be planted in the open ground early in spring, and will, in the case of the single varieties, bloom the same season. Or they may be planted in August or September, and will come up early in spring and make vigorous plants, which will bloom freely during late spring and early summer. They do well in sun or half shade. No other plant has so airy a grace as the Columbine, is more generous of blooms, or better adapted for cut flowers. In this mixture are shades of yellow and orange, blue and white, pure white, pink, dark red, and the red and yellow native Columbine, many of them having long spurs. Packet, 5 cents.

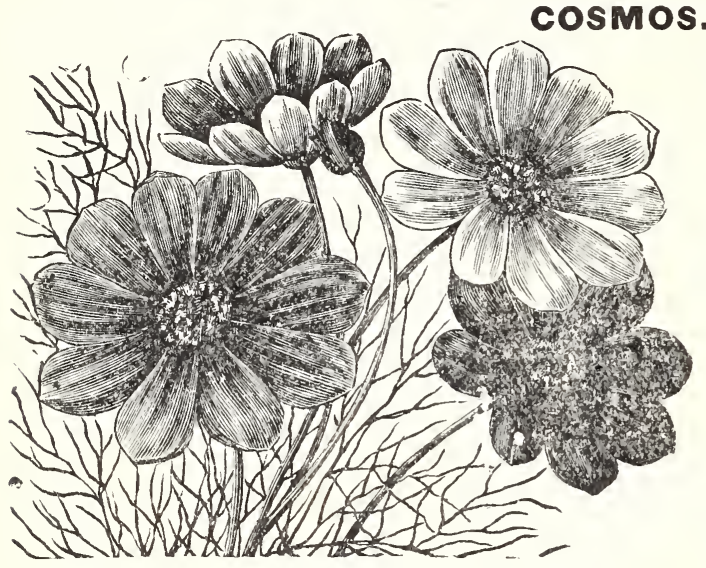

Should be sown in spring, in the open ground, when danger from frost is past, or the seed may be started under cover and afterwards transplanted. When the plants are about a foot high, the tops should be pinched out to induce a bushy growth, and this should be continued until the middle of July, when they should have formed nice, bushy plants three feet high by the same in diameter.

Large Flowered Perfection. Mixed. Packet, 5 cents.

DAHLIA.

A well-known favorite. The colors and shades of flowers are many; is a half-hardy peremnial, tuberous rooted, deserving a place in every garden. Blooms till frost. Keep roots during winter in a dry cellar,free from frost.

Various Colors. Double. Five feet. Packet, 10 cents

Various Colors, Single. Five feet. Packet, 10 cents

\section{FOUR O'CLOCK.}

Marvel of Peru, or Four O'clock, is a very pretty annual of vigorous growth. The flowers are brilliant, singularly mixed and varied on the same plant. 'Two feet. Packet, 5 cents.

\section{FORGET-ME-NOT.}

Half-hardy perennial. Six inches. Fine mixed. Packet, 5 cents.

\section{CAILLARDIA (Blanket Flower).}

One of the most showy and brilliant of garden flowers. Packet, 5 cents.

GERANIUM. Mixed, 10 cents per packet.

\section{HELIOTROPE.}

The Heliotrope is a sweet-scented, tender perennial. Grows freely in the garden or greenhouse. Fine for boquets. Two feet. Fine mixed. Packet, 5 cents.

\section{HOLLYHOCK.}

One of the most majestic of hardy plants, and a clump or line in any garden gives an effect not attainable with any other plant. For planting among shrubbery or forming a background for other flowers it is without equal. The seeds offered have been sared from the finest double flowers. Packet, 5 cents.

\section{LARKSPUR. (Delphinum.)}

The Larkspurs are showy annuals and perennials; beautiful border flowers. Foliage much divided, flowers in terminal spikes, blue, purple, white and red. The blue flowers are very brilliant. All grow freely in good soil. Mixed colors. Packet, 10 cents.

\section{LOBELIA.}

Very dwarf plants, growing four to six inches high and forming dense masses of flowers. of easy culture and well adapted for bedding, edging, pots or rookeries.

Finest Mixed Varieties. Packet, 5 cents.

\section{LUPINS.}

Mixed. Showy hardy plants from 2 to 3 feet tall. Packet, 5 cents. 
MARIGOLD.

Marigolds are showy annuals of easy culture.

Mixed Double. (Tall French Marigold.) Packet, 5 cents.

\section{MIGNONETTE.}

No annual is a more general favorite than the Mignonette. Its modest, sweet-scented flowers recommend it to every one. Of the easiest culture, it adapts itself to all situations. Finds a place in the greenhouse or observatory, in a box or pot on the window in some narrow, pent-up alley, or in the open ground in the summer.

Machet Dwarf. Large red. 6 inches. Packet, 5 cents.

\section{FLOWERING MOSS OP PORTULACA.}

One of the most showy and beautiful of border flowers. The seed germinates freely and flourishes in almost any situation. Does not grow over six inches high. Anyone can grow it in any garden.

Grandiflora Mixed. Large flowers of 15 to 20 colors mixed. Packet, 5 cents.

Double Flowering. Mixed colors, very fine Packet, 10 cents.

\section{MIXED ANNUALS FOR OLD FASHION WILD FLOWER GARDEN}

Bright colored, summer flowering, easily grown, hardy annuals, in the greatest varieties. Packet 5 cents.

NASTURTIUM.

(See Cover.)

\section{NICOTIANA (Flowering Tobacco).}

A handsome genius of garden plants of the tobacco family; 3 feet high. Packet 5 cents

\section{PANSY.}

Pansies are the most popular of all the flowers grown from seed.

For summer blooming sow the seed in a box in the house or in a moderate hotbed in February or March. Sow thinly, or else transplant when an inch high to one or two inches apart. Give the plants air, so that they may not spindle up, and they may be hardened, for transplanting to the open ground, which may be done when spring has fairly opened. The soil may be any good garden soil, but the size and the beauty of the flowers will be much increased by a liberal amount of well-rotted manure (cow manure is best) well worked in. A light clay loam is best of all soils, but good results may be had from any except light, poor sandy soil, or heavy, wet clay. A little shade is preferable to an entirely exposed situation. Remember that very large flowers can only be grown in rich soil and with sufficient moisture.

Improved Trimardeau Giant. A desirable and very attractive strain. The plants are of compact, robust and free-flowering habit. The flowers of immense size, measuring four inches in diameter; of good substance and unsurpassable in beauty and variety of coloring. Per packet, 10 cents.

Fine French Mixed. Packet, 10 cents.

\section{PHLOX.}

Phlox Drummondii. In all its varieties of colors and shades, comprising most elegant annual border flowers blooming from July to November; should have rich, light soil. The seed may be sown in hotbed in March, and the plants planted out in June, or, when the ground becomes warm, may be sown where they are to stand.

Finest Mixed. Very choice; various colors. 1 foot. Packet, 5 cents.

\section{POPPIES.}

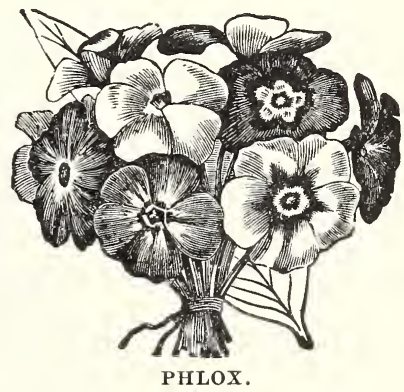

Shirley Single. A new strain of exceeding beauty. Flowers large and elegant, ranging in color from blush white through innumerable tints to pinks and crimson. Many exquisitely shaded. Splendid for cut flowers. 5 cents per pasket.

Double Mixed. All colors, mixed 5 cents per packet. 


\section{PETUNIAS.}

No plant is of more universal application than the Petunia. In the garden, conservatory or greenhouse it produces most beautiful flowers in great profusion. Will grow freely in any soil, but the richer the soil the better effect produced.

Mixed colors. 2 feet. Packet, 5 cents

\section{PERIWINKLE (Vinca), Packet, 5 cents.}

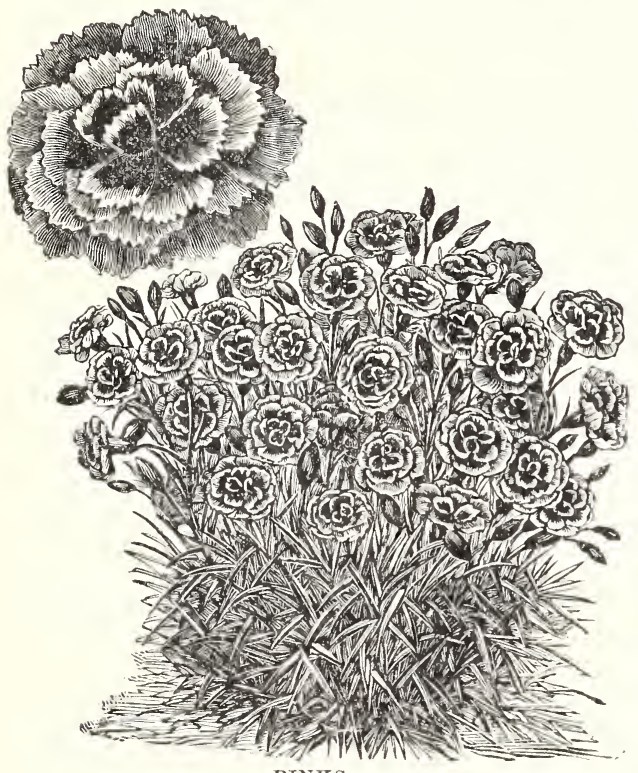

PINKS.

PINKS.

They bloom continually all summer and fall until severe frost; they live over winter and bloom finely again the second season. Plants ten to fifteen inches high, and are of the easiest cultivation.

Chinensis. China or Indian Pink. Finest double mixed. Packet, 5 cents.

Heddewiggii Double Japan Pinks. Fine collection of colors. Packet, 5 cents.

Imperialis. Double Imperial Pink. Fine mixed colors. Packet, 5 cents.

Finest Single. Mixed. Packet, 5 cents.

\section{SALVIA (Flowering Sage.)}

Of all the Salvias the Splendens is the brightest and best, well worthy of cultivation. Packet, 10 cents.

\section{WALLFLOWER (Coldlack)}

Well-known, deliciously fragrant, halfhardy annual and perennials, blooming early in the Spring, with spikes of beautiful flowers. They should be protected in a cold frame in the Winter and planted out in A pril. Single, Mixed. All colors. Packet, 5 cents

\section{SW EET PEAS.} (See Cover.)

\section{SALPICLOSSIS (Painted Tongue).}

Easy culture; almost orchid-like flowers. Packet, 5 cents.

\section{SCABIOSA or Mourning Bride.}

They grow about $2 \frac{1}{2}$ feet high and come into bloom early in July. Packet, 5 cents.

SNOW ON THE MOUNTAIN (Euphorbia). Packet, 5 cents. TEN WEEKS' STOCK.

Hardyannual; 1 foot high. Mixed. Packet, 5 cents.

Canary Yellow, Double. Packet, 10 cents.

SWEET WILLIAM.

Double. Finest mixed. Very large flowers. Packet, 5 cents.

Single. Finest mixed. Choice colors. Packet, 5 cents.

\section{VERBENA.}

No plant is more generally cultivated or more eagerly sought after than the Verbena, and no plant excels it for masses in beds on the lawns. They flower perfectly well from seeds sown in the spring. If started in the house in pots in winter, they will bloom sooner; but if sown in open ground in May they will bloom in August. Each plant will require a space of one foot.

Mammoth Mixed. Packet, 5 cents.

\section{VIOLETS. (Viola Odorata.)}

A great favorite, suitable for groups or borders; hardy perennial. Packet, 10 cents.

\section{ZINNIAS.}

A very showy plant, with large double flowers. Sow the seed early in the spring in open ground and transplant to one and one-half feet apart, in good rich soil. Half-hardy annual; one and one-half feet high.

Mixed Double. The colors run through all the shades of carmine, lilac, scarlet purple crimson, yellow, to pure white. Packet, 5 cents. 


\section{VINES AND CLIMBERS. MORNING GLORY, CONVOLVULUS MAJOR.}

New Imperial Japanese. The flowers are of gigantic size, measuring from four to six inches across. The colors are limitless in variety and very beautiful. Of easy culture and if sown early will produce magniticently. Per packet, 5 cents.

Common, Mixed. Large packet, 5 cents, ounce, 15 cents.

\section{MOON FLOWER.}

At night and during dull days the plants are covered with an abundance of large, pure white, fragrant flowers, five to six inches in diameter. Is a rapid grower, and within a few months will grow as much as forty feet. To insure germination take a sharp knife and cut a small nick in the shell of each seed, and soak in lukewarm water for about four hours before planting.

Packet, 5 cents.

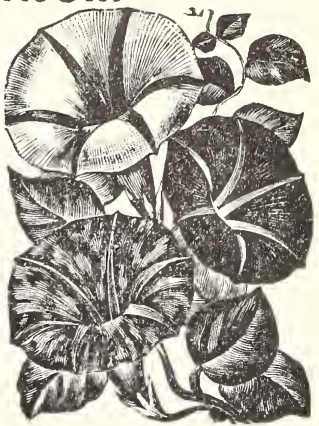

IMPERIAL JAPANESE MORNING GLORY.

\section{CYPRESS VINE.}

An elegant climbing plant with beautiful fern-like foliage and masses of beautiful star like flowers. Fifteen feet. Half-hardy annuals. Mixed. Packet, 5 cents.

\section{PASSION FLOWER.}

Purple, violet and white. The Passion Flower is a half-hardy perennial; in favorable situations grows vigorously and produces a profusion of beautiful flowers. Twenty feet. Packet, 10 cents.

\section{BALSAM APPLE AND PEAR.}

(Mormordica.)

Luxuriant annual climbers, with large leaves, making dense shade. The flowers are followed by ornamental fruits of orange or copper color, which burst and expose an interior of red that is highly effective. Often used for their medicinal qualities. Each, per Packet, 5 cents.

\section{COB FA.}

Scandens. Handsome bell-shaped flowers. Twenty feet. Packet, 5 cents.

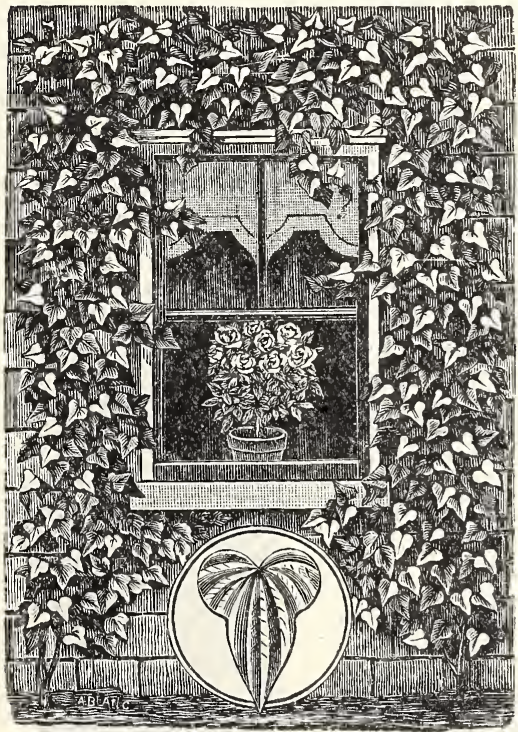

CHINESE CINNAMON VINES
WHLD CUCUMBER.

For covering porches and trellises. Packet, 5 cents.

\section{CHINESE CINNAMON VINES.}

Most desirable, easily grown, rapid climber.

Once planted will grow a life time. Beautiful and fragrant, white flowers, grows in shade or sun, in wet or dry season. No insects ever trouble it. No winter harms it. Plant any time up to June.

Price extra large bulbs, 3 to 5 inches long, 5 cents each; 50 cents dozen.

\section{MADERIA Or MIGNONETTE}

\section{VINE.}

One of the finest plants for rapidly covering trellis work we know of. Unexcelled for rapid growth. A great bloomer. Very sweet fragrance. Two for 5 cents and 5 cents each. 
ORNAMENTAL COURDS.

Dish Cloth or Bonnet Gourd. Packet, 5 cents.

Hercules' Club, Packet, 5. Dipper Gourd, Packet, 5c. Mixed Gourds, Packet, 5c HYACINTH BEAN.

Splendid climber, purple and lilac flowers. 10 to 20 feet high. Packet, 5 cents.

\section{SCARLET RUNNER.}

Will grow to the height of 12 to 15 feet; profusion of scarlet flowers. Packet, 5 cents.

WISTARIA.

Hardy climbing plants, making a rapid growth, with purple flowers. Packet, 10 cents.

\begin{tabular}{|l|l|}
\hline $\begin{array}{c}\text { Price of any of these Bulbs } \\
10 \text { Cents Each } \\
3 \text { for } 25 \text { cents. }\end{array}$ & SPRING BULBS. \\
\hline
\end{tabular}

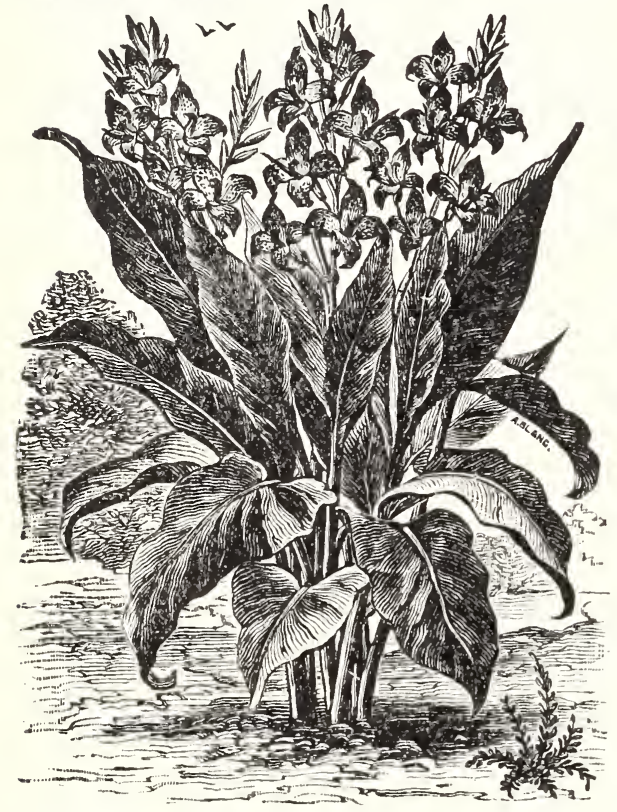

CANNAS.

\section{EVER-BLOOMINC CANNAS.}

Richard Wallace. Rich canary yellow, lower petals spotted crimson.

King Humbert. Scarlet flowers, bronze leaves, greatest favorite today. Height $4 \mathrm{ft}$.

Eureka. White with green leaves.

Alamania. Pleasing dark salmon with golden markings. Height. $4 \mathrm{ft}$.

President. Bright crimson.

Wyoming. Red with gold borders.

Hungaria. Large flower of rosy pink.

Louisiana. Deep red with green leaves.

\section{THE TUBEROSE.}

The frequent failures in getting blooms from the Tuberose come from three causesthe planting of bulbs that have already bloomed, or of those that having been too cold in winter have rotted in the center, something that cannot readily be seen; or thirdly from planting out to early, by which the same thing is caused. If anxious to have them bloom early in the summer they may be started in a hotbed or warm place in the house. Besides this they really will bloom as soon if planted in the open ground in a sunny spot the last of May as in ordinary treatment on the other plan. Rich soil, sun and moisture are required. Set bulbs with tops just above the ground.

Double Dwarf Pearl. Extra large Bulbs. 5 cents each; 50 cents a dozen.

\section{IMPORTED DUTCH BULBS.}

In fall we expect to have a complete and well selected assortment of Dutch Bulbs direct from the best bulb gromers in Holland, and they are always first class in quality.

Our assortment consists of Hyacinths, Tulips, Crocus, Narcissus, etc., all of which should invariably be planted in fall.

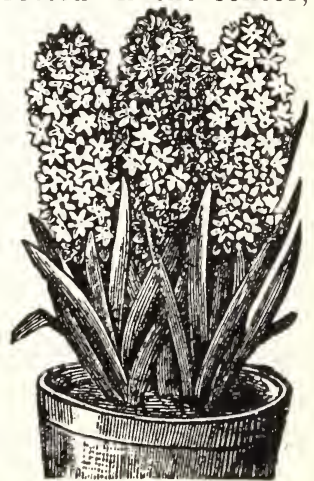




\section{THE CLADIOLUS.}

Plant the bulbs four inches deep and six inches apart in rows one to two feet distant in rich soil, preferably a light one. Plant at any time from the first day of May to the middle of June, and as they grow tie them to sticks. If very dry, abundantly water them. In the fall when the tops are dead, take them up, pull off the old bulbs and throw them away and store the new ones in some dry place where they will not freeze.

A fine mixture of named varieties, none but the best kinds, at 50 cents per dozen; $\$ 3.25$ per 100

\section{DAHLIA.}

Single and Double. Named sorts of various colors, each 10 cents ; 3 for $25 \mathrm{c}$; $90 \mathrm{c}$ per doz.

\section{CALADIUM.}

(Elephant's Ear.)

The foliage of this tropical plant is of immense size. It is particularly striking when grown either single or in a group on the lawn, with Cannas in the center. Will flourish anywhe 25 cents each.

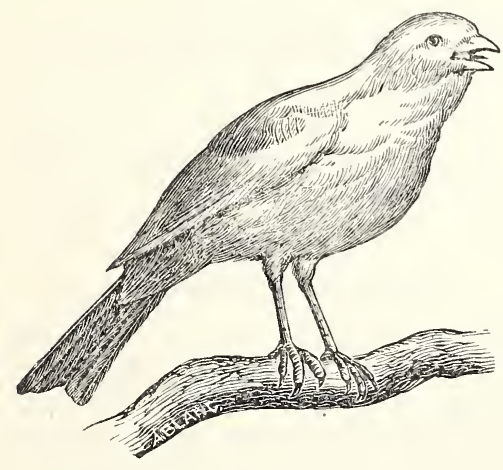

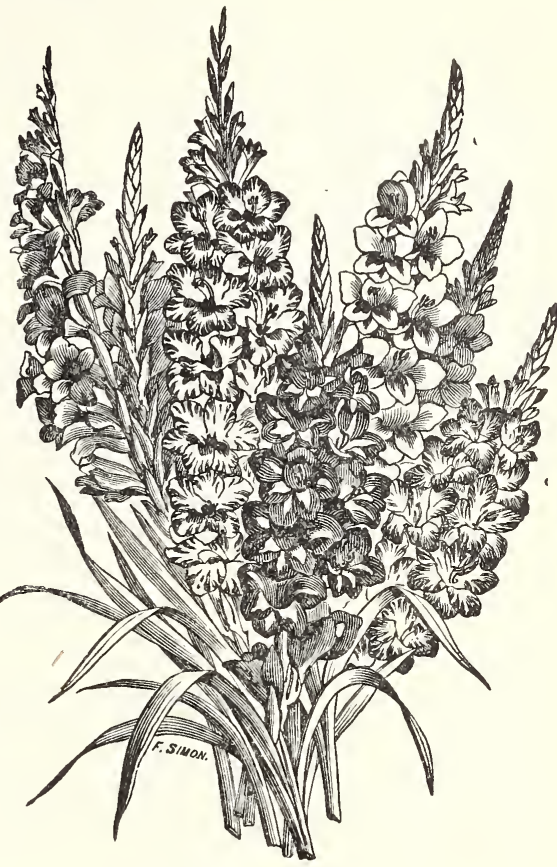

GLADIOLUS.

It is important to use good bird seed, and much sold in packages is inferior. Our stock is compos ed of the best imported, consisting of Sicily Canary, Russian Hemp, German Rape and Italian Millet.

Bird Manna. An invaluable food for birds 15 cents, 2 for 25 cents. Bird Pies, 15 cents each 2 for 25 cents.

Mocking Bird Food. 50 cents per pound.

Sunflower.

Cuttle Fish Bone.

Snow Drift Gravel for birds and gold fish. 10 cents per box, 3 for 25 cents.

Silver Gravel. 10 cents per box. Red Gravel. 10 cents per box. Bird Joy. Fine song Restorer 35 cents per box.

Bird Bitters. A tonic for birds when out of health. Per bottle, 25 zents.

Birdolene. Will keep your canary in health and song. 20 cents per box.

Canary Bigh Ball. Promotes song, aids digestion, affords amusement and exercise. 15 cents each, 2 for 25 cents.

Fish Food. 10 cents per box.

Bird Baths. 15 cents each. Bird Cups. 10 and 15 cents each.

\section{TRANSPORTATION CHARGES TO BE PAID BY PURCHASER}




\section{SWEET PEAS}

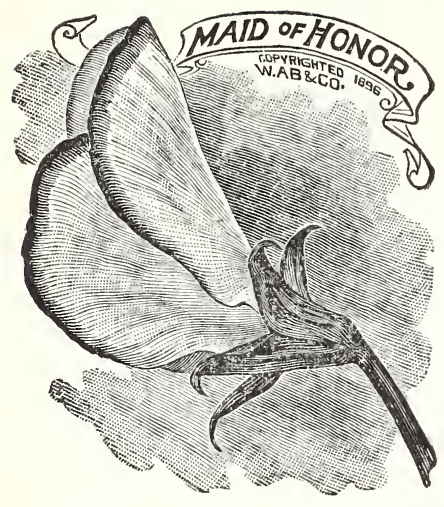

Seed should be sown as early as the ground can be worked in the spring, to enable the vines to get a good strong growth before the warm weather comes. Prepare the ground by thoroughly working in a large quantity of well-rotted manure. Make a trench six inches deep; in this sow the seed and cover two inches deep. As soon as the plants begin to show through, fill the trench. This will secure a deep planting without the bad effect of deep covering of the seed at first, and so enable the plant to bloom continually through the heat of the summer. As the flowers come into full bloom or fade, they should be cut off, for if the pods are allowed to form the plants will stop blooming. Each of the following named varieties of Sweet Peas 5c. per packet, 10c. per ounce. Mixed, 5c. per packet, 10c. per ounce, 30c. per quarter pound, $\$ 1.00$ per pound.

AGNES ECKFORD BEAUTIFUL. PINK.

AMERICA - Bright cardinal and white striped.

APPLE BLOSSOM-Shaded pink and rose.

BLACK KNIGHT-Deep maroon.

BLANCHE BURPEE-Large white.
CAPTAIN OF THE BLUES-Purplish mauve blue.

FIREFLY-Bright crimson scarlet.

MAID OF HONOR-White, edged blue.

PRIMROSE-Pale primrose yellow.

TRY THE NEW SPENCER VARIETIES. Mixed or separate colors, 20c per ounce.

\section{EVERLASTING, OR HARDY SWEET PEA.}

Showy, free-flowering climbers for covering old stumps, fences, etc.; continualls in bloom; fine for cutting. Hardy Perennial. Mixed colors, Packet, 10 cents.

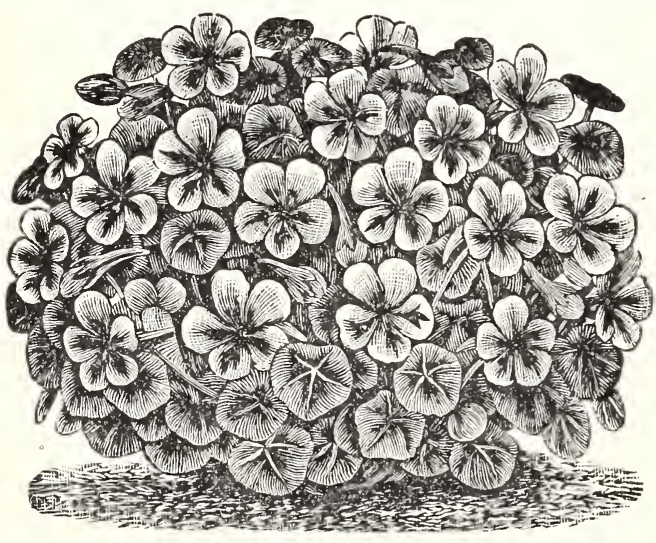

NASTURTIUM.

\section{NASTURTIUM.}

Dwarf Varieties. The improved varieties of the Dwarf Nasturtium are among the most popular and beautiful of our garden plants. Their neat compact growth, rich colored flowers and free blooming and long lasting qualities, together with their adaptability to almost any soil or situation, make them unsurpassed for garden decoration. One foot. Packet, 5 cents; ounce, 10 cents.

Tall Varieties. Elegant and luxuriant climbers for verandas, trellises, etc., bearing their gorgeous flowers in profusion until killed by frost. May be used to cover unsightly railings and to trail over rough ground with fine effect. Four to six fect. Packet, j cents; ounce, 10 cents. 


\section{Fertilizer for Home Gardens}

The subject of fertilizers is one on which an immense amount of investigation has been expended, and so much data made available that the home gardener who seeks information for the scientific books may easily become confused.

In the home garden the fertilizer problem is very simple, and the points which one should know in order to apply this stimulant to growth with good effect, and without much expense, are very few.

There are three chemical elements of plant food commonly used in fertilizers. They are ammonia (nitrogen), phosphates and potash. The first has been proven by experiments to stimulate in particular the leaf growth of plants; the second stimulates stalk and stem growth, and the last assists the development of fruits.

Nitrate of soda, the most popular form of nitrogen, will make fruit trees grow and bear more fruit, and make flowers bloom more brightly; but its chief effect is on the leaf growth. Each of the other plant foods if used in reasonable amounts, not in excess, will improve the general condition of plants to which it is applied, but its chief effect is in the direction $I$ have indicated. A balanced fertilizer is one which contains all three, and which gives a complete diet to the crop. And the composition of the balanced fertilizer is commonly expressed in a formula of three numbers with hyphens between, thus 5-8-7. The first of these always indicates the proportion of nitrogen contained in the mixture; the second, the proportion of phosphates, the third the proportion of potash. Thus 5-8-7 fertilizer contains five parts of nitrogen, to 8 of phosphates, and 7 of potash.

It is useless to bother with analysis of soils for garden crops. The practical value of chemical analysis of soils is a matter of doubt. Food elements may be present in the soil without being easily available to the plants. The chemical fertilizers are immediately soluble, and thus quickly available. All food is taken up by plants in liquid form. With the shallow rooted garden crops it is important to place the fertilizer close to the surface. Sprinkle it between the rows after cultivation every week or two. A little frequently applied is the best way. Overdoses of fertilizer are likely to be injurious, and one would better err on the side of too little than too much. You will be surprised at the difference a small application of fertilizer will make in your crops, if regularly applied. It will be days before it can be seen.

The garden needs a medicine chest, and one of the staple remedies which should be kept there in every garden is nitrate of soda. It is the cheapest and best form of nitrogen for fertilizer use, and may be used on anything which has suffered a check in growth. It is dangerous to use carelessly because it will burn foliage if it touches. Sprinkle it on the ground at the rate of a teaspoon to the plant, or dissolve it in water and pour this water on the roots. Nitrate is a complete fertilizer to plants which are grown for their leaves. It may be applied regularly to lettuce, cabbages, all kinds of green, endive, kale, etc. It is also good for flowers of all kinds, and is an excellent stimulant for grass when quick growth is desirable.

Sulphate of ammonia is a nitrogen fertilizer which creates in soil an acid reaction. It is being used extensively on golf greens, where an acid soil is desirable because it encourages particularly the growth of bent grass, and discourages many weeds and clover.

Bone meal is an excellent fertilizer for flowers. For roses, tulips, iris, and all annuals, it may be applied with good effect. It contains nitrogen and phosphate chiefly, and a good percentage of lime, which tends to sweeten the soil. Lime itself is not a fertilizer, but is always beneficial to garden soils, except for a few crops, of which potatoes are one. It sweetens the soil, and seems to make food elements already present more available to the plants.

\section{We carry in stock}

$\begin{array}{lc}\text { Bone Meal } & \text { Blood and Bone } \\ \text { Nitrate of Soda } & \text { Pulverized Sheep Manure } \\ \text { Sulphate of Ammonia } & \text { Shredded Cow Manure } \\ \text { Dried Blood } & \text { Vigora \& Sacco } \\ \text { Zempke's Liquid Plant Life for all Pot Plants and Ferns }\end{array}$


$(x+1 \quad y=2$

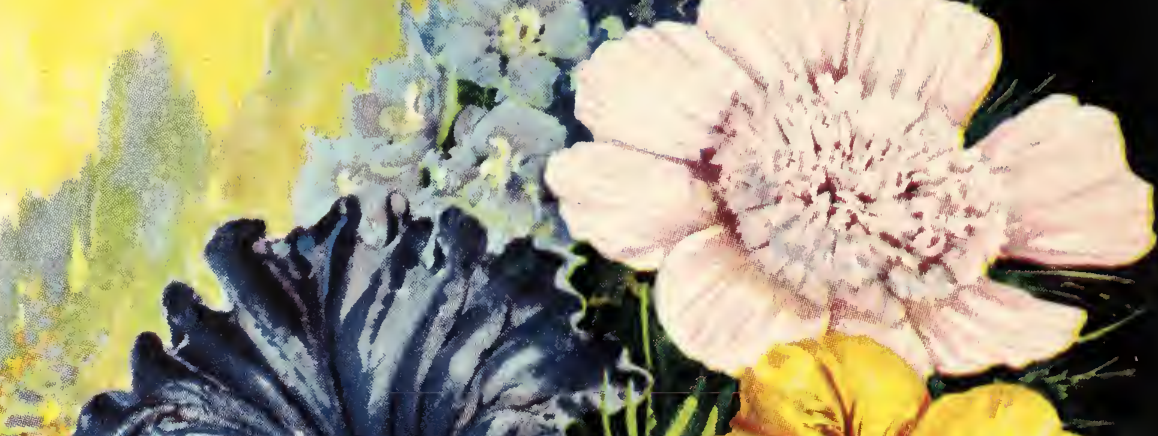
1. $2^{2}=42$ 1

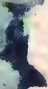

$=486$

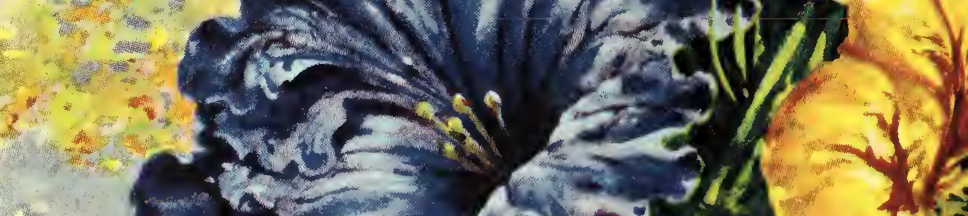

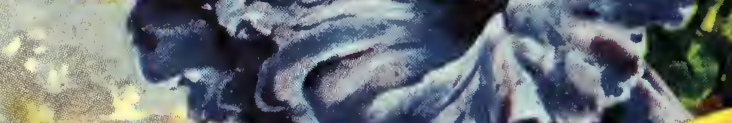

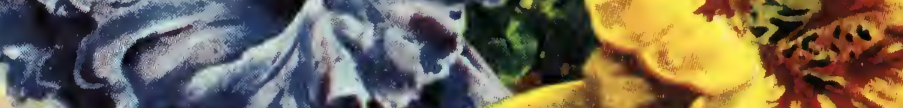

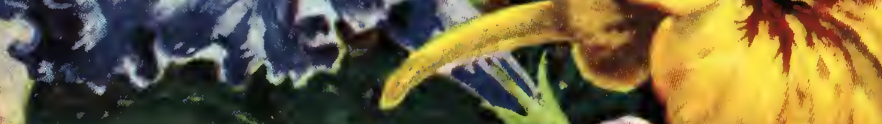

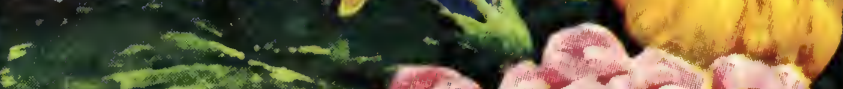

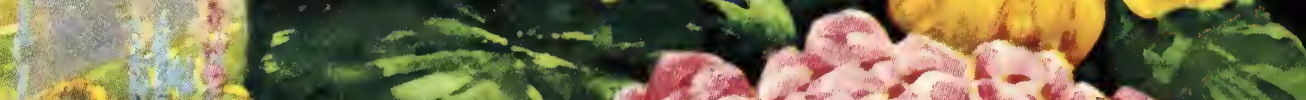

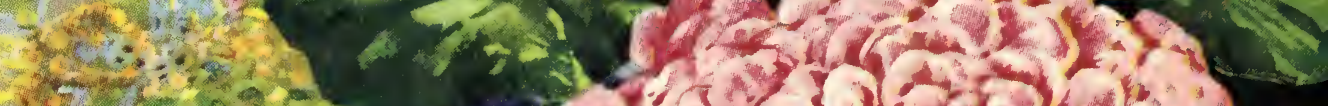

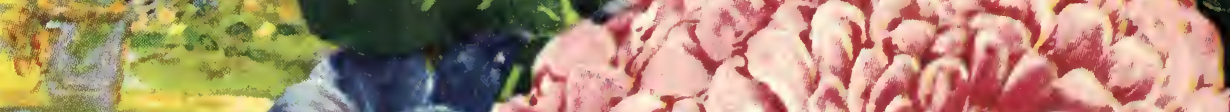

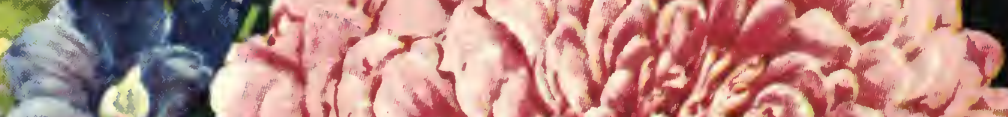
- 1 a r n w

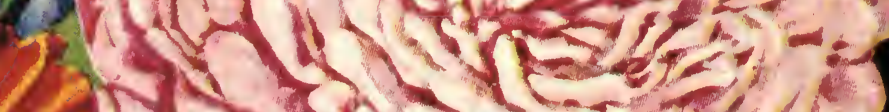
N a -2,

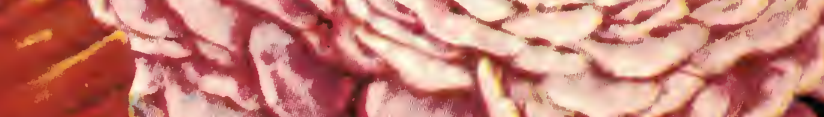

$6+\infty$
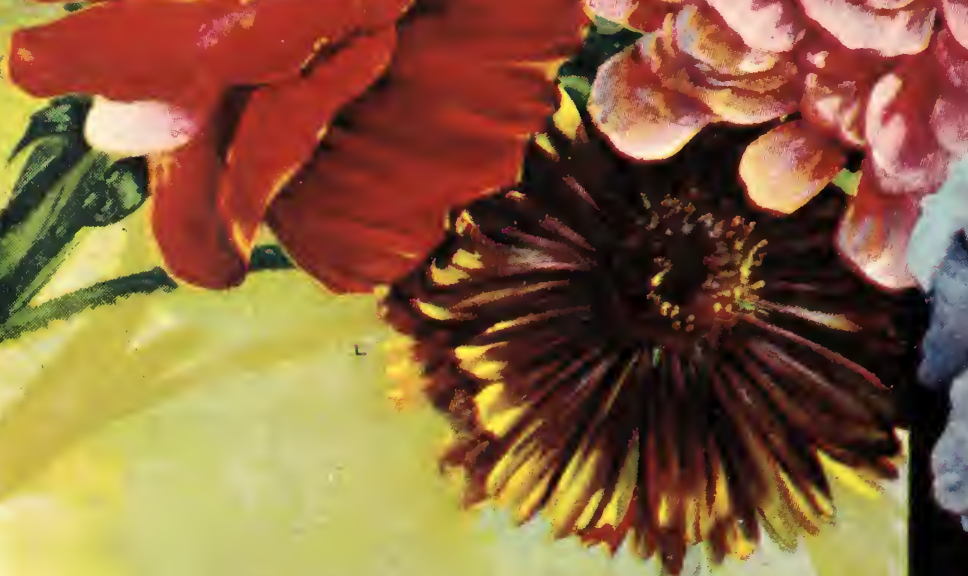